Surface and Bulk Carbonate Formation in Calcium Oxide during $\mathrm{CO}_{2}$ Capture

Dr David Vega-Maza

School of Engineering

Fraser Noble Building (Room 256)

King's College

Aberdeen

AB24 3UE

(Tel direct) +44(0)1224 272672

(Fax general office) +44(0)1224 272497

(Email) d.vega-maza@abdn.ac.uk 


\title{
Surface and Bulk Carbonate Formation in Calcium Oxide during $\mathrm{CO}_{2}$ Capture
}

\author{
Greg A. Mutch, James A. Anderson and David Vega-Maza* \\ School of Engineering, University of Aberdeen, Aberdeen, United Kingdom
}

Tel: +44 1224 272672, Email: d.vega-maza@abdn.ac.uk

\begin{abstract}
Calcium looping ( $\mathrm{CaL}$ ), the cyclic carbonation and calcination of limestone, is a prominent carbon capture option considering reduced parasitic energy consumption compared to amine scrubbing. The main issue preventing application is sorbent performance decay during cycling. Therefore hydration and extended carbonation reactivation strategies, as well as synthetic approaches to enhance or sustain reactivity, are of interest. Results of an investigation are presented on the impact of reactivation strategies on carbonate formation through detailed study using in-situ infrared spectroscopy. Surface and bulk carbonate formation regimes were readily distinguished allowing the influence of temporal, hydration and thermodynamic conditions within each regime to be studied. Surface chemistry of $\mathrm{CaO}$ during two initial cycles was shown to change. Significantly, it was shown that the $\mathrm{CaO}$ surface produced from the calcination of $\mathrm{Ca}(\mathrm{OH})_{2}$ possessed more highly reactive sites compared to the surface produced from $\mathrm{CaCO}_{3}$. The presence of water enhanced bulk carbonate formation at $300{ }^{\circ} \mathrm{C}$ and influenced the complexation of surface carbonates during looping. The results are of interest in the CaL community, offering molecular scale explanations for macroscale observations, whilst also informing on the role of humidity in direct air capture and sorption enhanced reaction processes.
\end{abstract}

\section{Keywords}

Calcium looping

Surface chemistry

In-situ infrared spectroscopy

Carbon capture, utilisation and storage (CCUS)

Carbonate formation

Hydration

\section{Introduction}

Carbon capture is an integral part of a holistic approach to climate change mitigation whether from concentrated industrial and energy sources or directly from air (Boot-Handford et al., 2014). The major challenges associated with the capture stage are related to energetic and economic expenditure, to provide a competitive and effectual process. 
Calcium looping (CaL) is a carbon capture process(Abad et al., 2015; Abanades, 2002; Blamey et al., 2010; Shimizu et al., 1999) that has attracted significant attention largely due to high quality recoverable heat from an exothermic adsorption stage (Perejon et al., 2015). Furthermore, process similarities with existing circulating fluidized bed boilers, low cost/risk materials (limestone), the potential use of spent sorbent as a source of lime for cement production (Dean et al., 2011), favourable energetic comparison with $1^{\text {st }}$ generation amine scrubbing carbon capture processes (Hanak et al., 2016) and the possibility for inherent energy storage (Hanak and Manovic, 2015), all suggest CaL could be a frontrunner in future climate change mitigation strategies. Flue gases are contacted with fluidised $\mathrm{CaO}$ particles at around $650{ }^{\circ} \mathrm{C}$ in a carbonating reactor to produce $\mathrm{CaCO}_{3}$, before particles enter a calciner at $900^{\circ} \mathrm{C}$ where a purified stream of $\mathrm{CO}_{2}$ is produced for transport and storage or utilisation. The process has been successfully piloted at scale (up to $1.9 \mathrm{MW}_{\text {th }}$ ) (Arias et al., 2013; Chang et al., 2014; Gonza et al., 2010; Sanchez-Biezma et al., 2013; Ströhle et al., 2014) including sorbent reactivation strategies (Champagne et al., 2015; Diego et al., 2016). This latter point introduces the major disadvantage of $\mathrm{CaL}$; sorbent deactivation related to morphological and reactivity changes. $\mathrm{CaO}$ molar conversion decays to around $7-8 \%$ after extended cycling (Grasa and Abanades, 2006). A prominent characteristic of the carbonation reaction is the dual-regime; a kinetically controlled "fast" reaction followed by a diffusion controlled "slow" regime(Barker, 1973) with the switchover defined by a critical product layer thickness (Alvarez and Abanades, 2005). However as calcination can be conducted to achieve full conversion to $\mathrm{CaO}$, there is an implication that irreversible changes to oxide reactivity occur during operation. This is due to high temperature sintering promoted by $\mathrm{CO}_{2}$ and $\mathrm{H}_{2} \mathrm{O}$ (Borgwardt, 1989), attrition (Scala et al., 2007) and sulfation (D. Y. Lu et al., 2009) or the presence of impurities (Manovic et al., 2009) that circulating particles experience.

Efforts to combat sorbent deactivation or enhance conversion have included: the use of careful precursor selection to provide increased residual conversion in synthetic calcium oxide sources (Liu et al., 2010); thermal pre-treatment of limestone (Manovic and Anthony, 2008); doping of natural and synthetic sorbents (Al-jeboori et al., 2013, 2012; H. Lu et al., 2009; Reddy and Smirniotis, 2004); the use of stabilising supports/binders (Antzara et al., 2015; Broda et al., 2012; Broda and Müller, 2014; Chen et al., 2009; Filitz et al., 2012; Huang et al., 2010; Li et al., 2005; Manovic and Anthony, 2009); intuitive synthetic approaches to prevent sintering (Sedghkerdar et al., 2014; Zhang and Li, 2004) and finally polymorphic sorbents (Clough et al., 2016; Zhao et al., 2014). Alternatively, approaches to reactivate spent sorbent have received a large amount of attention, also in combination with synthetic approaches as above (Blamey et al., 2016; González et al., 2015; Manovic et al., 2013). Both sorbent preparation and reactivation strategies have been reviewed recently (Erans et al., 2016). The main contenders for reactivation are steam hydration (Coppola et al., 2015; Manovic and Anthony, 2007; Materić et al., 2010) and extended carbonation (Arias et al., 2012; Lysikov et al., 2007). Steam hydration following calcination, mechanistically explained by a shrinking core model (Blamey et al., 2015), produces $\mathrm{Ca}(\mathrm{OH})_{2}$ which has a high reactivity towards $\mathrm{CO}_{2}$, and if hydration is conducted in the presence of $\mathrm{CO}_{2}$, a high mechanical stability can be achieved(due to enhanced annealing effects) (Materic et al., 2010). Generally hydration lowers attrition resistance of $\mathrm{CaO}$, but the precise impact depends on hydration time(Coppola et al., 2014). The presence of 
steam during calcination enhances sintering (Borgwardt, 1989) and provides a stable porous sorbent morphology when compared to calcination without steam (Donat et al., 2012). The presence of steam during carbonation enhances product layer diffusion (Manovic and Anthony, 2010). However it is generally agreed that hydration between calcination and carbonation stages in a separate reactor would be favoured from a process design consideration ( $\mathrm{Yu}$ et al., 2012). This is due to the reliance on the "fast" regime in application and therefore the limited significance of enhanced product layer diffusion. Pre-hydration also appears to have a particularly favourable impact on performance for ambient temperature carbon capture, dramatically increasing breakthrough times (Ridha et al., 2015). Recently the $\mathrm{CaO} / \mathrm{Ca}(\mathrm{OH})_{2}$ couple has also been investigated at pilot plant level for thermochemical energy storage (Rougé et al., 2017).

Questions remain regarding the exact mechanism of hydration and subsequent enhanced activity in CaL. Initial work assumed that hydration followed by dehydration in the presence of $\mathrm{CO}_{2}$, in other words the direct carbonation of $\mathrm{Ca}(\mathrm{OH})_{2}$, resulted in lower conversion due to enhanced stability of $\mathrm{Ca}(\mathrm{OH})_{2}$ above its decomposition temperature in the presence of $\mathrm{CO}_{2}$ - termed "superheated dehydration" (Materic et al., 2010). Furthermore it has been shown that when direct carbonation is conducted, a simple dehydration (as might be expected considering the temperature conditions employed in the carbonator) followed by carbonation of $\mathrm{CaO}$ is not sufficient to explain observed kinetics (Materic and Smedley, 2011). It was proposed that due to slow dehydration in the presence of $\mathrm{CO}_{2}$, the carbonation reaction proceeded via an adsorbed water film on a $\mathrm{Ca}(\mathrm{OH})_{2}$ surface (Materic and Smedley, 2011). The mechanism is further complicated by particle size effects and textural properties (Materic et al., 2014). $\mathrm{Ca}(\mathrm{OH})_{2}$ pellets and hydrated natural limestone exhibited "superheated dehydration", evidenced by two water evolution stages when heated under $\mathrm{CO}_{2}$, whereas $\mathrm{Ca}(\mathrm{OH})_{2}$ powder and dolomite did not (Blamey et al., 2011). The small particle size in the case of $\mathrm{Ca}(\mathrm{OH})_{2}$ and the small $\mathrm{CaO}$ grains separated by inert $\mathrm{MgO}$ in dolomite could not develop a product layer of critical thickness, and therefore no second stage of water evolution was observed upon product layer breakage. Thus it was suggested that the "superheated dehydration" effect was kinetic in nature and only applicable to larger particles (Blamey et al., 2011).

In this work prominent issues surrounding calcium looping are investigated primarily through the use of in-situ FTIR, as has been previously called for to further elucidate the role of molecular water (Materic et al., 2015). It is proposed that the onset of the "slow" regime can be spectroscopically identified through an increase in the integrated intensity of spectral features due to vibrational modes of bulk carbonate, initiated at a lower temperature in the presence of water or hydroxyl groups on the surface of particles; $300^{\circ} \mathrm{C}$ as compared to $400^{\circ} \mathrm{C}$ in the absence of water. Through the use of $\mathrm{CO}_{2}$ and $\mathrm{D}_{2} \mathrm{O}$ as probe molecules (the latter as a proxy for water but with vibrational modes in wavenumber region devoid of other absorption bands) the initial stages of carbonate formation and water adsorption were monitored during the first two cycles of a calcinationcarbonation loop. $\mathrm{D}_{2} \mathrm{O}$ adsorption perturbed carbonate formation and showed that the surface of $\mathrm{CaO}$ produced from $\mathrm{Ca}(\mathrm{OH})_{2}$ possessed more highly reactive surface sites than $\mathrm{CaO}$ produced from $\mathrm{CaCO}_{3}$ calcination. 


\section{Experimental}

\subsection{Materials}

$\mathrm{Ca}(\mathrm{OH})_{2}$ was used as purchased (Sigma-Aldrich, $>96 \%$ ) and as a source of CaO following suitable in-situ calcination at high temperature in-vacuo during two stages. High surface area $\mathrm{CaCO}_{3}$ was synthesised using optimised conditions (in terms of resultant surface area) following a published method (Wei et al., 1997). Briefly, an aqueous suspension of $\mathrm{Ca}(\mathrm{OH})_{2}$ (Sigma-Aldrich, > 96\%) was carbonated by flowing $\mathrm{CO}_{2}(\mathrm{BOC}, 99.8 \%$ ) in the presence of a dispersant (Dispex N40). High surface area was necessary to perform transmission infrared spectroscopy. Throughout the manuscript, reference to $\mathrm{CaO}$ implies after calcination of $\mathrm{Ca}(\mathrm{OH})_{2}$ unless specifically distinguished as originating from $\mathrm{CaCO}_{3}$. The calcination to obtain $\mathrm{CaO}$ involved an initial treatment under low vacuum $\left(<5 \times 10^{-3} \mathrm{mbar}\right)$ at $400^{\circ} \mathrm{C}$ for 15 minutes which was used to remove adsorbed water. The second stage involved extensive calcination under high vacuum $\left(<5 \times 10^{-6} \mathrm{mbar}\right)$ at $800^{\circ} \mathrm{C}$ for $2 \mathrm{~h}$. Calcination was conducted in the same manner for all apparatus where $\mathrm{Ca}(\mathrm{OH})_{2}$ was used as a $\mathrm{CaO}$ source, or to decompose formed carbonates after $\mathrm{CO}_{2}$ exposure. Calcination, by definition, refers to a thermal treatment in air. Throughout the manuscript, reference to calcination, although technically incorrect, is used to relate thermal treatments conducted in-vacuo here to the appropriate stage of the CaL process.

$\mathrm{CO}_{2}$ was used as supplied (BOC, 99.8\%) or as a mixture prepared gravimetrically containing $23 \%(\mathrm{v} / \mathrm{v}) \mathrm{CO}_{2}$ and balance $\mathrm{N}_{2}$ (BOC, 99.998\%). The composition of the mixture was confirmed by mass spectrometry (EcoSys- $\mathrm{P}^{\mathrm{TM}}$ ) and is henceforth referred to as diluted $\mathrm{CO}_{2}$. Both pure $\mathrm{CO}_{2}$ and diluted $\mathrm{CO}_{2}$ were used to fill glass bulbs attached to the vacuum line for exposure to samples as a probe molecule. The diluted $\mathrm{CO}_{2}$ mixture was used to enhance sensitivity in spectroscopic investigations as opposed to mimicking flue gas composition. Water (Ultra-Pure Grade I, $18.2 \mathrm{~m} \Omega \mathrm{cm}$ ) and deuterium oxide (Sigma-Aldrich, 99.9 atom \% D) were used as probe molecules after freeze-pump-thaw degassing cycles until no further dissolved gases were evolved.

\subsection{Characterisation}

Surface area and porosity measurements were conducted using a Micromeritics Tristar with $\mathrm{N}_{2}$ as adsorbate. Powdered samples ( $c a .0 .1 \mathrm{~g}$ ) were treated at $200^{\circ} \mathrm{C}$ in flowing $\mathrm{N}_{2}$ for $3 \mathrm{~h}$ to remove adsorbed water. Analysis was conducted at liquid nitrogen temperature, with the Brunauer-Emmett-Teller (BET) method (Brunauer et al., 1938) applied to determine surface area and the Barrett-Joyner-Halenda (BJH) method (Barrett et al., 1951) applied to determine pore volume and pore size distribution.

X-ray diffraction data were collected on an Empyrean diffractometer (PANalytical, NL) using Cu-Ka radiation ( $\lambda=$ $1.54 \AA$ A ). Powdered samples ( $c a .0 .2 \mathrm{~g}$ ) were supported in aluminium holders after loose packing. Patterns were collected from $19-61^{\circ} 2 \theta$ with a step size of $0.026^{\circ}$ and a total collection time of $10 \mathrm{~min}$.

\subsection{In-situ FTIR}


A high vacuum line (Figure 1) fitted with a spectroscopic cell was used to collect in-situ transmission infrared spectra of self-supporting discs formed from calcium looping sorbents. These were subsequently exposed to $\mathrm{CO}_{2}$, $\mathrm{H}_{2} \mathrm{O}$ and $\mathrm{D}_{2} \mathrm{O}$ at a variety of temperatures, with spectral acquisition and interpretation performed to elucidate the identity and behaviour of newly formed surface and bulk species.

\begin{tabular}{|r|r|}
\hline & \multicolumn{1}{|c|}{ Instrument List } \\
\hline Displayed Text & Description \\
\hline PR 1 & Edwards 0 - 1000 mbar Pressure Transducer \\
\hline PR 2 & RS Components 0 - 760 Torr Pressure Transducer \\
\hline PR 3 & Edwards $10^{-7}-10^{-2}$ mbar Penning Gauge \\
\hline TC 1 & Zenith 0 - 270 V Variac \\
\hline TR 1 & K-Type Thermocouple \\
\hline
\end{tabular}

Low Vacuum

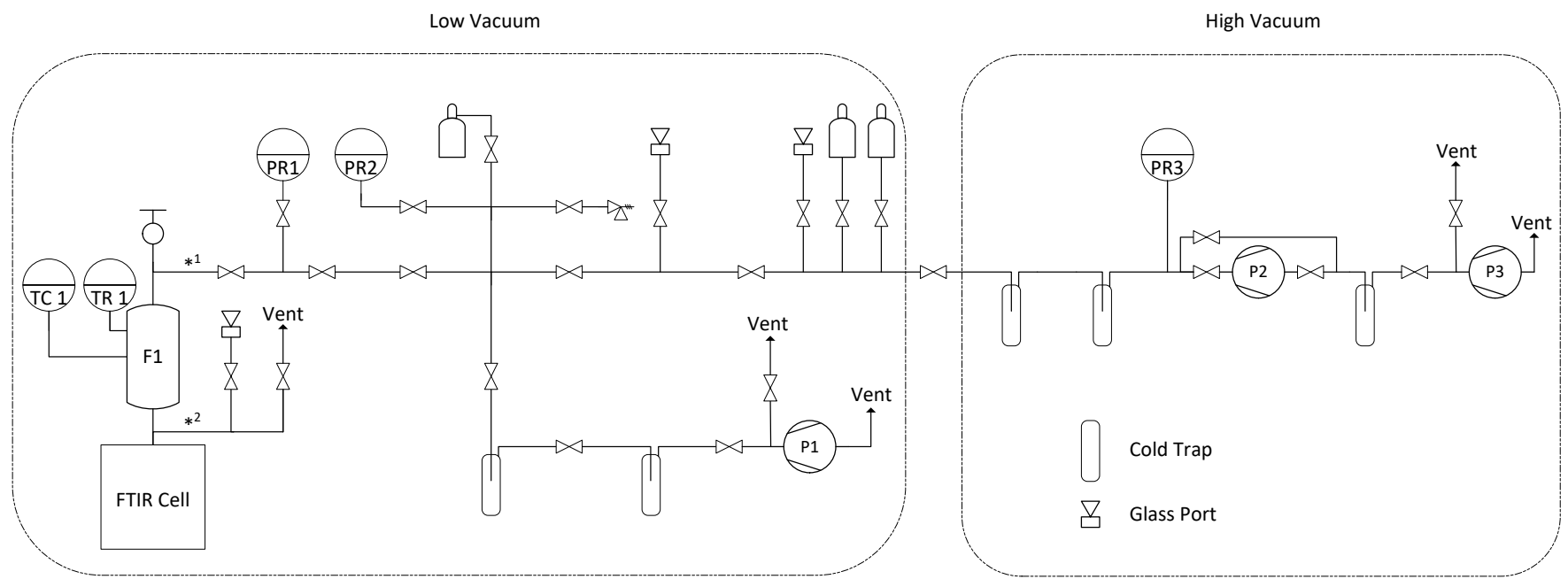

\begin{tabular}{|r|r|}
\hline \multicolumn{2}{|c|}{ Equipment List } \\
\hline Displayed Text & Description \\
\hline F1 & Watlow 120 V, 350 W Furnace \\
\hline P1 & Edwards E2M2 Rotary Vane Vacuum Pump \\
\hline P2 & Custom Glass Oil Diffusion Pump \\
\hline P3 & Varian DS 102 Rotary Vane Vacuum Pump \\
\hline
\end{tabular}

Figure 1 - Schematic of the high vacuum line apparatus with instrument and equipment lists (inset).

Powdered samples (ca. $20 \mathrm{mg}$ ) pressed at 2 tons into $\varnothing 16 \mathrm{~mm}$ self-supporting discs (Specac 15.011 Manual Hydraulic Press) were loaded into a custom-made quartz holder, before being introduced into the cell and furnace section of the high vacuum apparatus. Vertical movement of the disc between furnace and cell was affected by the use of a hoist system. Through the manipulation of Young's valves, low pressures of $\mathrm{CO}_{2}(<50$ Torr), diluted $\mathrm{CO}_{2}\left(<50\right.$ Torr), water ( $<15$ Torr) and $\mathrm{D}_{2} \mathrm{O}$ (<17.5 Torr) were incrementally exposed to samples suspended in the furnace and/or cell region to produce spectroscopic adsorption isotherms. In this way, the development of surface and bulk species was monitored with increasing pressure, temperature or time. Although archaic, pressures are reported throughout in Torr (760 Torr $=101325 \mathrm{~Pa}$ ) for clarity and ease of comparison between figures.

To investigate the prominent issues surrounding carbonation and the impact of water, a series of experiments were designed. The procedures are introduced with more detailed discussion provided during interpretation of results. In a first experiment, a $\mathrm{Ca}(\mathrm{OH})_{2}$ disc was calcined following the two stage calcination described above, to produce $\mathrm{CaO}$. This was subsequently exposed to increasing pressures of $\mathrm{CO}_{2}$ at room temperature to monitor carbonate formation. By conducting exposure at room temperature, reaction was limited to the surface (i.e. limited to the "fast" regime). The same disc was then re-calcined following the same procedure, before $\mathrm{CO}_{2}$ exposure again. Overall this procedure simulated the first two cycles of a calcium looping process (where often the greatest decrease in capacity is observed), allowing any changes to the mechanism of carbonate formation 
to be understood. In a second experiment, the entire procedure was repeated with a fresh sample of $\mathrm{Ca}(\mathrm{OH})_{2}$, but with $\mathrm{D}_{2} \mathrm{O}$ exposure (as a vapour at room temperature) immediately following calcination and before exposure to $\mathrm{CO}_{2}$. In this way the effect of water on the formation of surface carbonates, as well as any changes to the water adsorption mechanism (and therefore surface chemistry) in the first two cycles could be understood. Furthermore, in separate experiments, $\mathrm{D}_{2} \mathrm{O}$ was exposed (as a vapour at room temperature) to $\mathrm{CaO}$ produced from $\mathrm{Ca}(\mathrm{OH})_{2}$ or $\mathrm{CaCO}_{3}$ (again both following the same calcination procedure). This experiment allowed a comparison between $\mathrm{CaO}$ surfaces produced from the respective parent materials $\mathrm{Ca}(\mathrm{OH})_{2}$ and $\mathrm{CaCO}_{3}$.

Subsequent experiments involved spectroscopic monitoring during calcination/carbonation of $\mathrm{Ca}(\mathrm{OH})_{2}$, in a variety of gas compositions at different temperatures (including high temperatures to initiate bulk carbonate formation), to understand the impact of water or time on carbonate formation. In the first, $\mathrm{CaO}$ was produced from $\mathrm{Ca}(\mathrm{OH})_{2}$, with $\mathrm{CO}_{2}$ exposed before heating and spectral acquisition at distinct temperatures. A variant of this experiment involved collection of spectra after $\mathrm{CO}_{2}$ exposure at a fixed temperature, with spectral acquisition on a temporal basis. In two further separate experiments, $\mathrm{Ca}(\mathrm{OH})_{2}$ was heated in-vacuo or in the presence of $\mathrm{CO}_{2}$ with spectral acquisition at distinct temperatures. In a final experiment, water vapour was introduced to $\mathrm{Ca}(\mathrm{OH})_{2}$ at room temperature. The disc was then heated to $100{ }^{\circ} \mathrm{C}$ in the presence of water vapour, to simulate the presence of steam, before $\mathrm{CO}_{2}$ exposure and spectral acquisition at distinct temperatures. For all experiments, unless otherwise specified, for any given experimental temperature, samples were equilibrated at constant temperature for $15 \mathrm{~min}$ prior to spectral acquisition.

Spectra were collected using a Perkin Elmer Spectrum 100 spectrometer equipped with a liquid $\mathrm{N}_{2}$ cooled MCT detector. Spectra were collected as an accumulation of 100 scans, over a range of $4000-1000 \mathrm{~cm}^{-1}$ at a resolution of $4 \mathrm{~cm}^{-1}$ with automated background subtraction. Spectral data were collected in transmission mode and transformed to absorbance. In most cases spectra were subtracted from an initial spectrum following calcination (before $\mathrm{CO}_{2}$ or $\mathrm{D}_{2} \mathrm{O}$ exposure), so that any growth in a spectroscopic feature was attributed to a change in the chemistry of the sorbent. Where spectra are reported as difference plots it is stated explicitly. In some cases, for clarity, raw experimental spectra were reported.

\section{$2.4 \mathrm{CO}_{2}$ Gravimetric Adsorption}

Adsorption isotherms were obtained using a force restoration electronic microbalance system $\left(\mathrm{Cl}\right.$ Precision $^{\circledR}$ MK2-G5) with a sensitivity of $0.1 \mu \mathrm{g}$. The microbalance system was coupled to a high vacuum apparatus, similar to the FTIR spectroscopic apparatus, and equipped with an identical furnace. Powdered samples (ca. $50 \mathrm{mg}$ ) of $\mathrm{Ca}(\mathrm{OH})_{2}$ were loaded into a fritted quartz bucket after a zero and $50 \mathrm{mg}$ calibration procedure (Mettler Toledo E2 Calibration Weight, $50 \pm 0.0020 \mathrm{mg})$.

$\mathrm{CO}_{2}$ adsorption was studied on $\mathrm{Ca}(\mathrm{OH})_{2}$ or $\mathrm{CaO}$ produced from calcination of $\mathrm{Ca}(\mathrm{OH})_{2}$ as described in 2.1. In both cases, data logging at a frequency of 1 sample every $6 \mathrm{~s}$ was initiated (following two stage calcination in the case of $\mathrm{CaO}$ ) allowing a 10 min stabilisation period for an initial mass of sorbent to be obtained, which was used in 
subsequent conversion calculations. In the case of $\mathrm{CaO}$, full decomposition was achieved before data acquisition was initiated. The highest pressure of $\mathrm{CO}_{2}$ used in the FTIR investigations (50 Torr) was exposed to the calcined sample under isothermal conditions and allowed to equilibrate over $24 \mathrm{~h}$. A triplicate repeatability investigation was conducted at an intermediate temperature $\left(400^{\circ} \mathrm{C}\right)$ where a significant level of conversion was attained. In the case of $\mathrm{Ca}(\mathrm{OH})_{2}$, a similar experiment was conducted under non-isothermal conditions. Attempts were made to introduce water vapour continuously to maintain an overpressure, but as the furnace area was at far higher temperature than the rest of the apparatus, extensive condensation ultimately prevented the application of an isothermal approach for $\mathrm{Ca}(\mathrm{OH})_{2}$.

\section{Results}

\subsection{Characterisation}

Surface area and porosity analysis (Table 1 ) showed that $\mathrm{Ca}(\mathrm{OH})_{2}$ possessed a low surface area and mesopores with a low total pore volume. Upon calcination to $\mathrm{CaO}$, surface area approximately doubled with a $37 \%$ reduction in average pore width, accompanied by an increase in pore volume. $\mathrm{CaCO}_{3}$ surface area was $28 \mathrm{~m}^{2} \mathrm{~g}^{-1}$, lower than the value determined in the source publication, but still reasonably high for calcite (Wei et al., 1997). All $\mathrm{N}_{2}$ adsorption-desorption isotherms (Supplementary Information, S1a) were of Type IV by IUPAC classification and displayed hysteresis indicating condensation in mesopores. Pore size distribution plots (Supplementary Information, S1b) indicated that the porosity of $\mathrm{Ca}(\mathrm{OH})_{2}$ was occurring across a wide range of pore widths, which upon calcination to $\mathrm{CaO}$ were concentrated in the $5-40 \mathrm{~nm}$ range, with a loss across higher pore width values. $\mathrm{CaCO}_{3}$ exhibited a similar pore size distribution to $\mathrm{CaO}$, concentrated beneath $30 \mathrm{~nm}$.

Table 1 - Surface area and porosity data for $\mathrm{CaCO}_{3}$ as synthesised, $\mathrm{Ca}(\mathrm{OH})_{2}$ as purchased and following calcination at $800{ }^{\circ} \mathrm{C}$ to produce $\mathrm{CaO}$.

\begin{tabular}{llll}
\hline Sample & $\begin{array}{l}\text { BET Surface Area } \\
\left(\mathrm{m}^{2} \mathrm{~g}^{-1}\right)\end{array}$ & $\begin{array}{l}\text { BJH Ads Cumulative Pore Volume } \\
\left(\mathrm{cm}^{3} \mathrm{~g}^{-1}\right)\end{array}$ & $\begin{array}{l}\text { BJH Ads Average Pore Width } \\
(\mathrm{nm})\end{array}$ \\
\hline $\mathrm{CaCO}_{3}$ & 28 & 0.14 & 20 \\
$\mathrm{Ca}(\mathrm{OH})_{2}$ & 15 & 0.08 & 19 \\
$\mathrm{CaO}$ & 30 & 0.10 & 12 \\
\hline
\end{tabular}

X-ray diffractograms are shown (Figure 2) for $\mathrm{Ca}(\mathrm{OH})_{2}$ and $\mathrm{CaO}$ derived from the former material by calcination at $800{ }^{\circ} \mathrm{C} . \mathrm{Ca}(\mathrm{OH})_{2}$ gave sharp well-defined peaks at $28.7,34.1,47.2,50.8$ and $54.4^{\circ} 2 \theta$ indicating a highly crystalline material of a brucite structure in reasonable agreement with ICSD PDF (01-072-0156). CaO was also highly crystalline and of a rock-salt structure with peaks at 32.2, 37.4 and $53.9^{\circ} 2 \theta$ in good agreement with ICSD PDF (01-075-0264). $\mathrm{CaCO}_{3}$ displayed peaks at 23.1, 29.4, 31.5, 36.0, 39.4, 43.2, 47.2, 47.6, 48.5, 56.5 and 57.4 $2 \theta$ in excellent agreement with ICSD PDF (01-083-0578). Application of the Scherrer equation, assuming a spherical shape factor, to the most intense reflections determined a mean crystalline domain size of $56.3 \mathrm{~nm}$ for $\mathrm{CaCO}_{3}$, $32.0 \mathrm{~nm}$ for $\mathrm{Ca}(\mathrm{OH})_{2}$ and $43.7 \mathrm{~nm}$ for $\mathrm{CaO}$. 


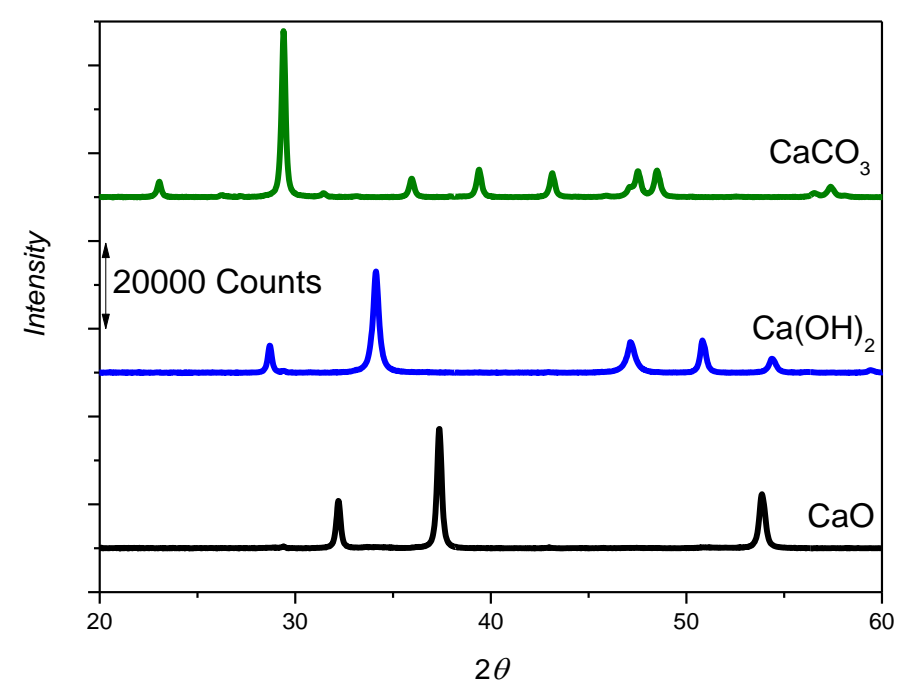

Figure 2 - X-ray diffractograms for $\mathrm{CaCO}_{3}, \mathrm{Ca}(\mathrm{OH})_{2}$ and $\mathrm{CaO}$.

\subsection{In-situ FTIR}

Upon exposure to increasing pressures (<50 Torr) of diluted $\mathrm{CO}_{2}\left(23 \%(\mathrm{v} / \mathrm{v}) \mathrm{CO}_{2}\right)($ Supplementary Information, S2) at room temperature, species identified as surface carbonates were formed on $\mathrm{CaO}$ by assignment of peaks in the $1800-800 \mathrm{~cm}^{-1}$ region (Figure 3). Upon coordination to a surface, the symmetry of the carbonate ion is lowered and thus certain vibrational modes are activated (Busca and Lorenzelli, 1982). Prominent vibrational bands at 1476 and $1416 \mathrm{~cm}^{-1}$ increased in intensity with increasing $p \mathrm{CO}_{2}$ and were assigned to the $v_{3}$ asymmetric $\mathrm{C}-\mathrm{O}$ stretch of monodentate carbonate species on the basis of $\Delta v<100 \mathrm{~cm}^{-1}$ (Figure 3a) (Anderson and Rochester, 1986; Busca and Lorenzelli, 1982). The small bands at 1072 and $874 \mathrm{~cm}^{-1}$ were assigned as $v_{1}$ symmetric $\mathrm{C}-\mathrm{O}$ stretch and $v_{2}$ out of plane deformation, respectively. Very weak absorption features around 1776, 1640 and $1214 \mathrm{~cm}^{-1}$, hardly visible on the scale in Figure 3, were tentatively assigned to very small amounts of bridging carbonate $\mathrm{C}-\mathrm{O}$ stretching, bicarbonate asymmetric $\mathrm{C}-\mathrm{O}$ stretching and $\mathrm{C}-\mathrm{O}-\mathrm{H}$ bending modes, respectively (Philipp and Fujimoto, 1992). In the second stage of the simulated looping process (Figure 3b) identical vibrational modes were identified. 

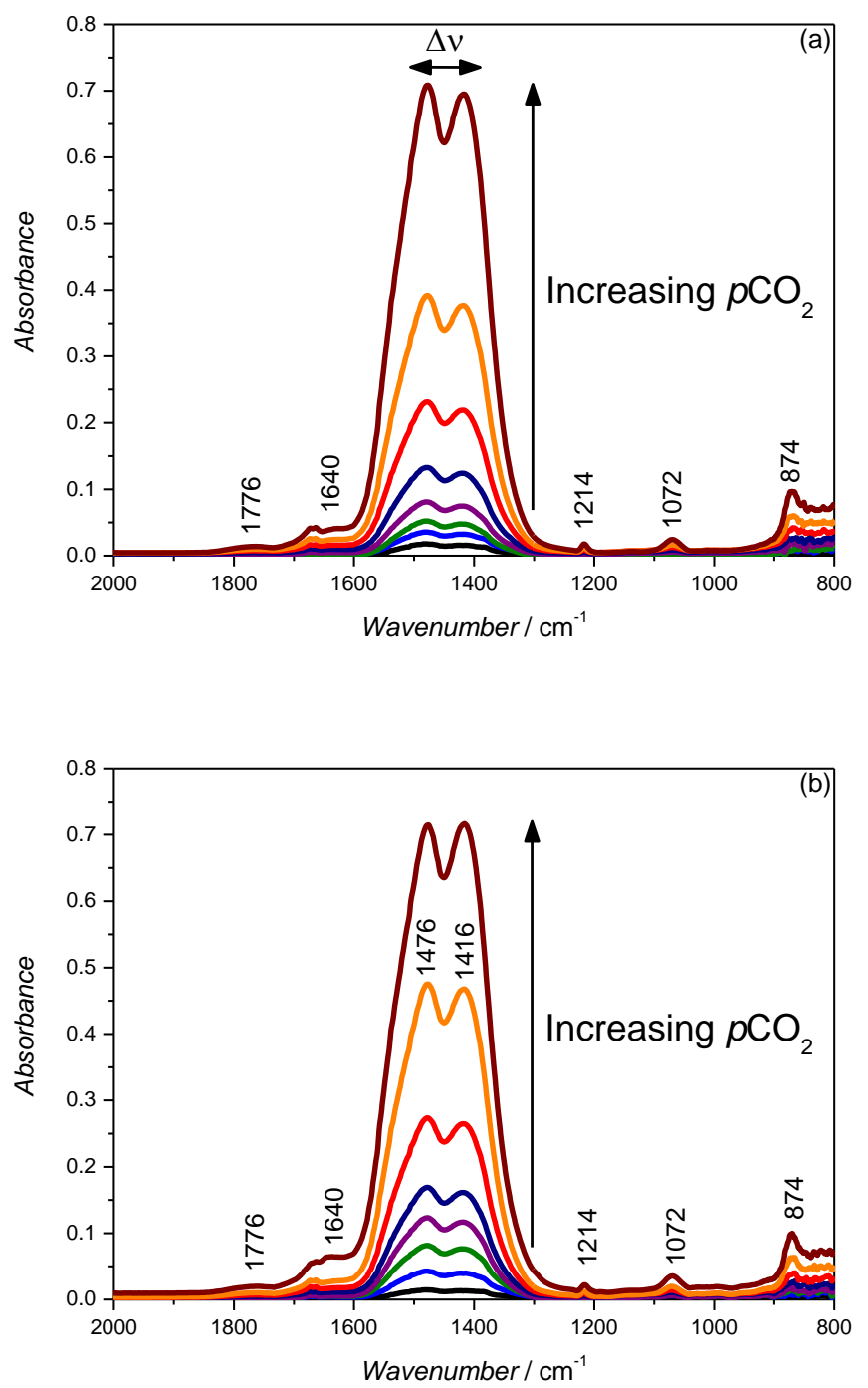

Figure 3 - FTIR difference spectra of (a) $\mathrm{CO}_{2}$ exposed at room temperature to $\mathrm{CaO}$ produced from $\mathrm{Ca}(\mathrm{OH})_{2}$ in $\mathrm{Loop} 1$ and (b) in Loop 2. 
Exposure of $\mathrm{CaO}$ to increasing vapour pressures of $\mathrm{D}_{2} \mathrm{O}(<17.5$ Torr) produced absorption bands due to dissociatively adsorbed and molecularly adsorbed deuterated surface species. Absorption maxima were apparent at 2722 and $2685 \mathrm{~cm}^{-1}$ at the highest exposed pressures with broad features at 2636 and $2625 \mathrm{~cm}^{-1}$ and a shoulder at $2690 \mathrm{~cm}^{-1}$ (Figure 4a \& c). A broad feature across a wide range $<2700 \mathrm{~cm}^{-1}$ was also visible in Figure 4a, reduced in intensity in Figure 4c. The band at $2722 \mathrm{~cm}^{-1}$ was due to the stretching mode of "free" O-D, with the broad band at $2625 \mathrm{~cm}^{-1}$ arising from a similar mode of "bound" O-D(Scheme 1), where "bound" and "free" distinguish O-D groups on the subsurface and surface layers respectively. The $2690 \mathrm{~cm}^{-1}$ shoulder was assigned as molecularly adsorbed deuterated water on a $\mathrm{Ca}(\mathrm{OH})_{2}$ pseudolattice. The band at $2685 \mathrm{~cm}^{-1}$ was shifted from an initial value of $2681 \mathrm{~cm}^{-1}$ at the lowest exposed pressure, and thus was tentatively assigned to a perturbed OD stretching mode from dissociative adsorption of $\mathrm{D}_{2} \mathrm{O}$ on a $\mathrm{Ca}(\mathrm{OH})_{2}$ pseudolattice. It was likely overlapped significantly by the band at $2690 \mathrm{~cm}^{-1}$. The broad band at $2636 \mathrm{~cm}^{-1}$ was due to physisorbed $\mathrm{D}_{2} \mathrm{O}$. All assignments were taken from Low et al., 1971.

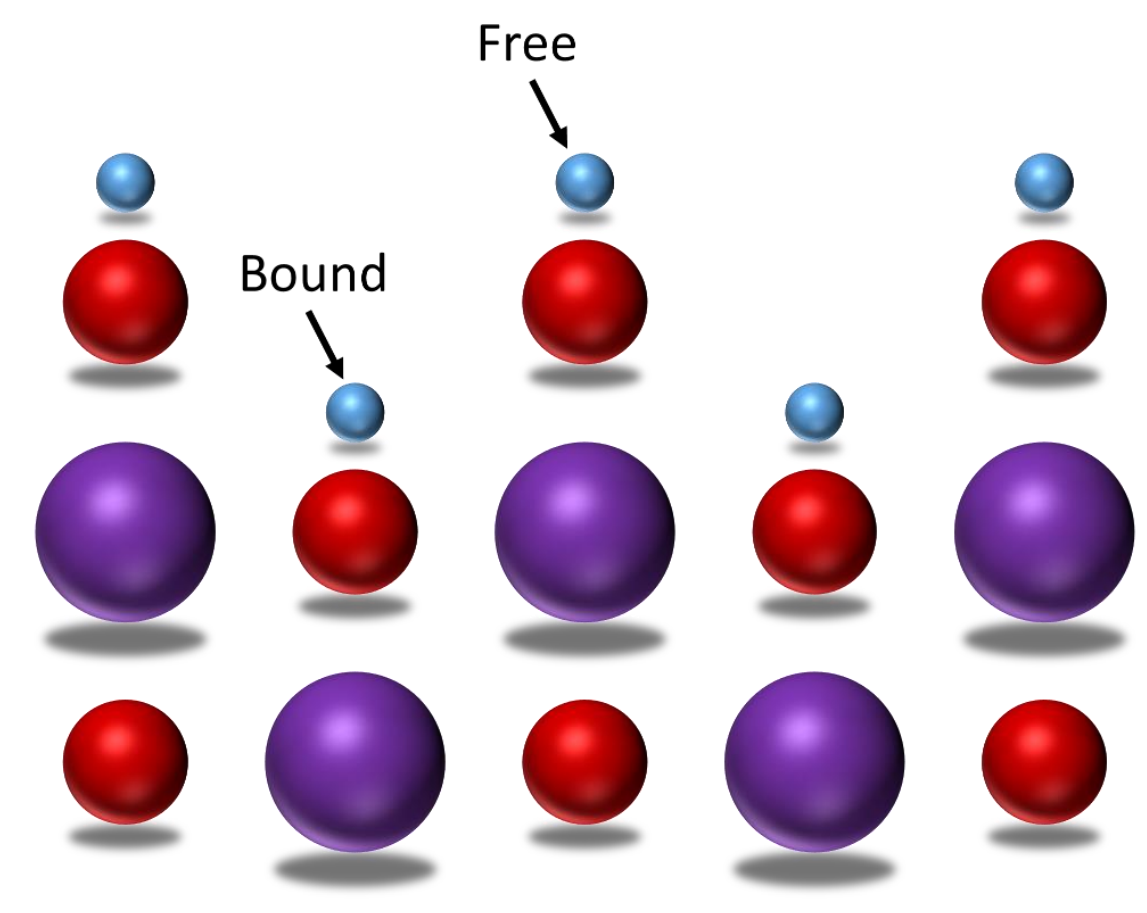

Scheme 1 - Calcium oxide (100) surface and deuteroxide species. O - red spheres, Ca - purple spheres, D - blue spheres.

Upon subsequent $\mathrm{CO}_{2}$ exposure (Figure $4 \mathrm{~b} \& \mathrm{~d}$ ) bands due to surface carbonate species were observed. The significant differences from the situation without $\mathrm{D}_{2} \mathrm{O}$ present on the surface (Figure 3 ) were a shift in position of the $1476 \mathrm{~cm}^{-1}$ band to $1487 \mathrm{~cm}^{-1}$ whilst the band at $1416 \mathrm{~cm}^{-1}$ remained in the same position. The intensity relationship, previously $1: 1$ was also modified by $D_{2} O$ present on the surface. Due to the shift in position it was reasonable to assume that the intensity of the $1487 \mathrm{~cm}^{-1}$ band increased as opposed to a decrease in the 1416 $\mathrm{cm}^{-1}$ band. Overall the intensity of bands due to carbonate species was significantly lower than in the absence of $D_{2} \mathrm{O}$. Identification of deuterated bicarbonate species was not possible due to the remaining $D_{2} \mathrm{O}$ species on the 
surface obscuring any possible band at ca. $2666 \mathrm{~cm}^{-1}$, assuming an isotopic shift ratio of 1.35 with respect to a $3600 \mathrm{~cm}^{-1} \mathrm{OH}$ group (Busca and Lorenzelli, 1982).
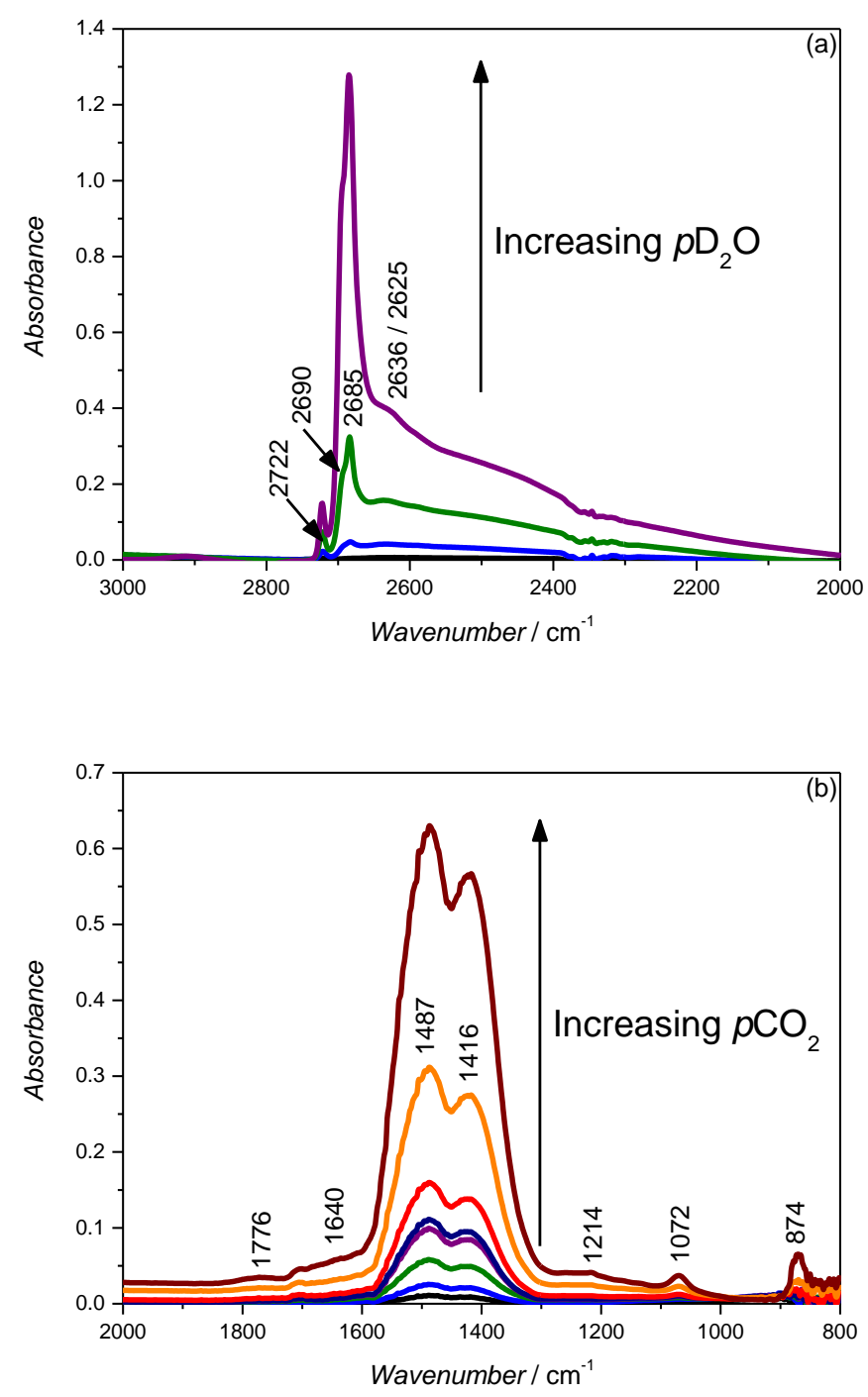

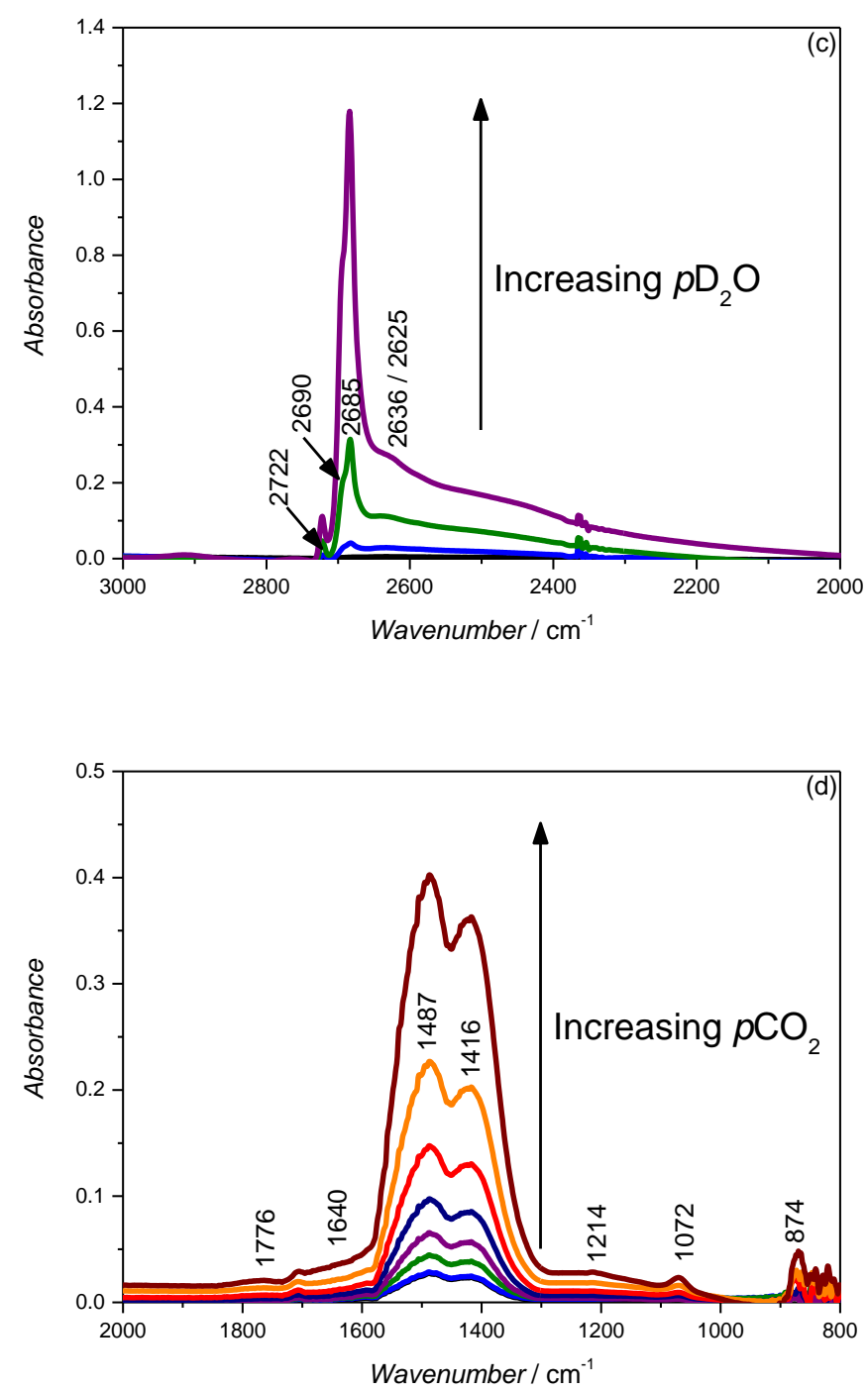

Figure 4 - FTIR difference spectra at beam temperature of (a) $\mathrm{D}_{2} \mathrm{O}$ exposure to $\mathrm{CaO}$ produced from $\mathrm{Ca}(\mathrm{OH})_{2}$ in $\mathrm{Loop} 1,(b) \mathrm{CO}_{2}$ adsorption in Loop 1, (c) $\mathrm{D}_{2} \mathrm{O}$ adsorption in Loop 2 and (d) $\mathrm{CO}_{2}$ adsorption in Loop 2.

A strong difference in adsorptive behaviour of identical vapour pressures of $\mathrm{D}_{2} \mathrm{O}$ on $\mathrm{CaO}$ produced from the calcination of $\mathrm{Ca}(\mathrm{OH})_{2}$ and $\mathrm{CaCO}_{3}$ was observed (Figure 5). Peaks due to the adsorbed species discussed above were observed, but the broadening observed $<2700 \mathrm{~cm}^{-1}$ was reduced on the oxide produced from the calcination of $\mathrm{CaCO}_{3}$ (Figure 5b). 

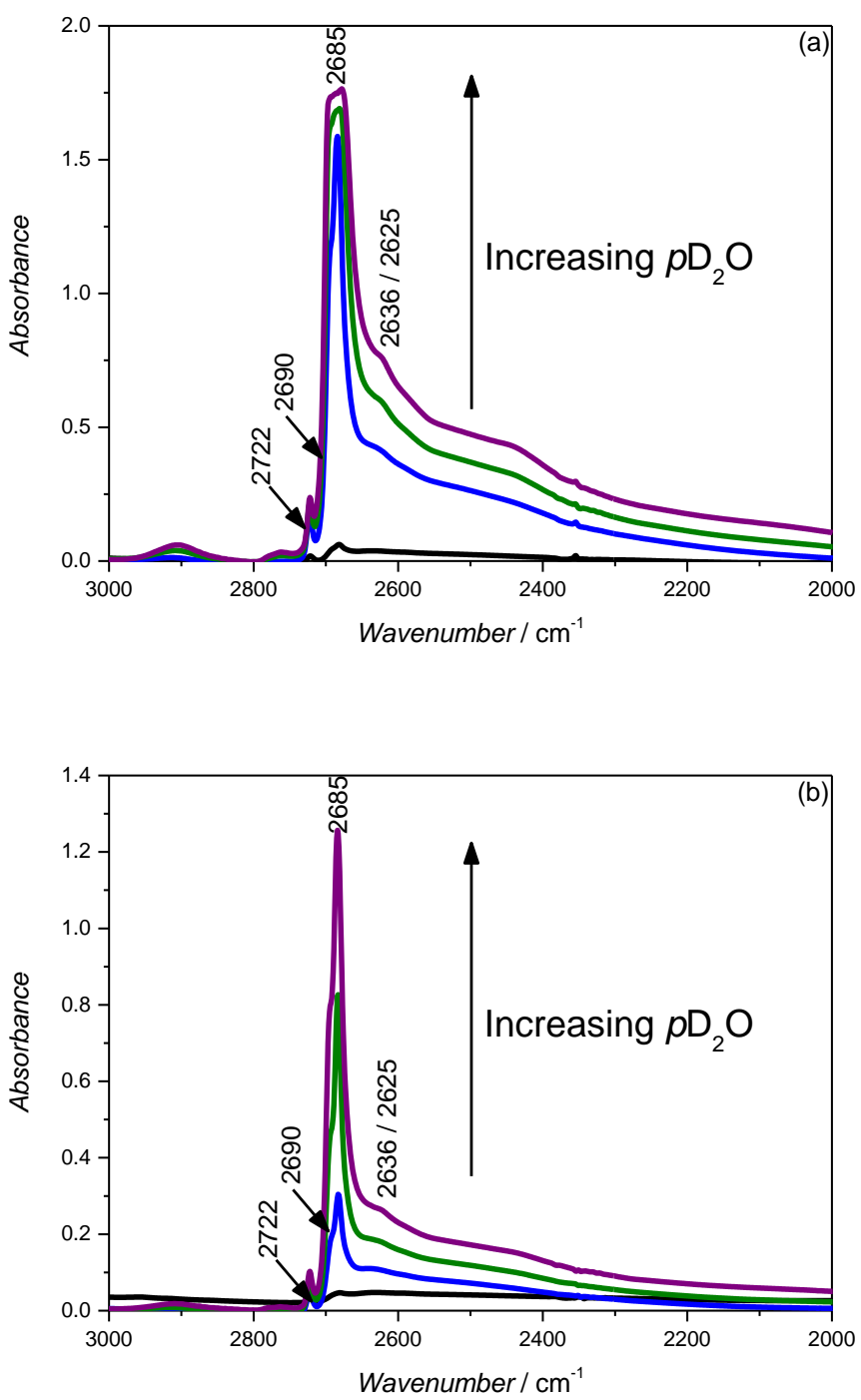

Figure 5 - FTIR difference spectra at beam temperature of (a) $\mathrm{D}_{2} \mathrm{O}$ adsorption on $\mathrm{CaO}$ produced from $\mathrm{Ca}(\mathrm{OH})_{2}$ and $(\mathrm{b}) \mathrm{D}_{2} \mathrm{O}$ adsorption on $\mathrm{CaO}$ produced from $\mathrm{CaCO}_{3}$. 

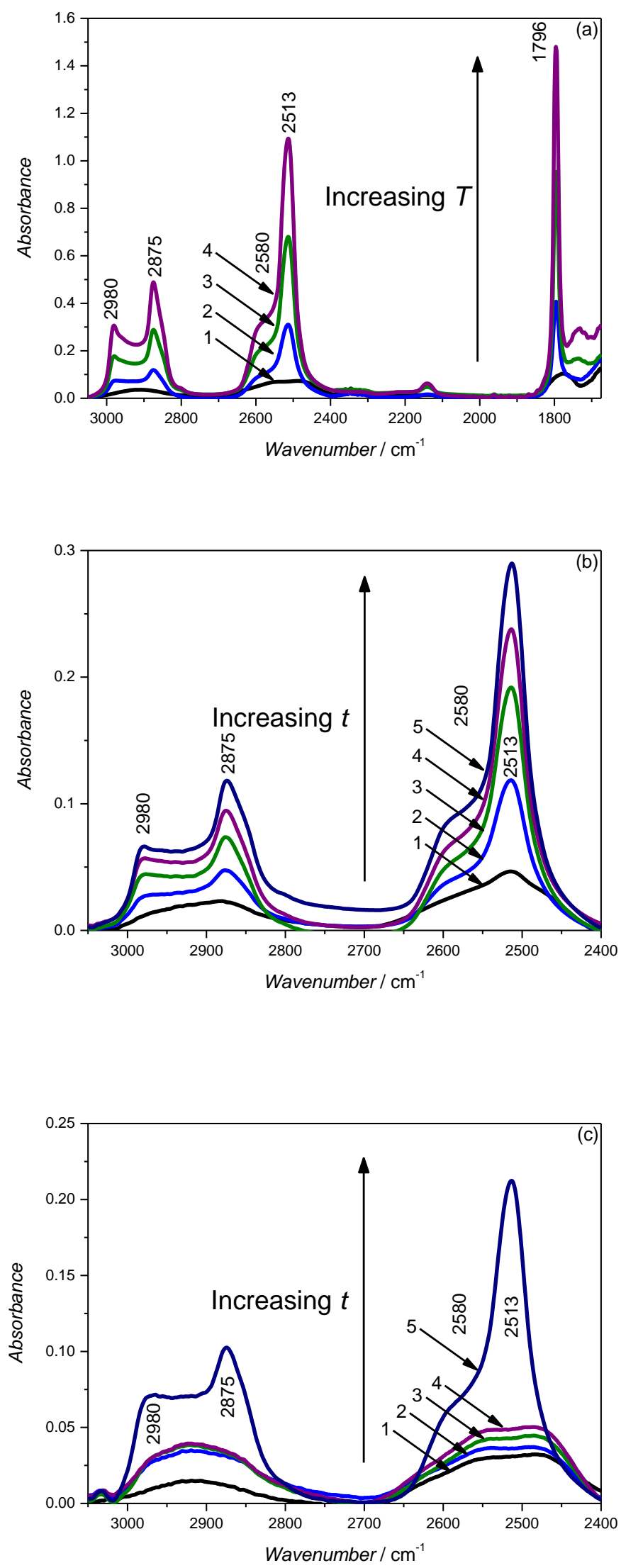

Figure 6 - FTIR difference spectra of (a) $\mathrm{CO}_{2}$ adsorption on $\mathrm{CaO}$ produced from $\mathrm{Ca}(\mathrm{OH})_{2}$ at $300(1), 400$ (2) $500(3)$ and $600^{\circ} \mathrm{C}(4)$, (b) $\mathrm{CO}_{2}$ adsorption on $\mathrm{CaO}$ from $\mathrm{Ca}(\mathrm{OH})_{2}$ at $400{ }^{\circ} \mathrm{C}$ after $1(1), 10(2), 30$ (3), 60 (4) and 180 minutes (5) and (c) $\mathrm{CO}_{2}$ adsorption on $\mathrm{CaO}$ produced from $\mathrm{Ca}(\mathrm{OH})_{2}$ at $350^{\circ} \mathrm{C}$ after $1(1), 10(2), 30(3), 60$ (4) and 180 minutes (5). 
Following contact with 50 Torr of $\mathrm{CO}_{2}$, the highest pressure in our previous investigations, and subsequent in-situ heating, well defined bands due to bulk carbonate species became apparent with the sample at $400^{\circ} \mathrm{C}$ and above (Figure 6a). In all previous experiments with samples below $400^{\circ} \mathrm{C}$, this spectral region remained devoid of features. Bands with maxima at 2980, 2875, 2580, 2513 and $1796 \mathrm{~cm}^{-1}$ were assigned to bulk carbonate species. The 2980 and $2875 \mathrm{~cm}^{-1}$ bands were assigned as first overtone $\left(2 v_{3}\right)$ from bulk calcite carbonate anions. Absorption at 2580 and $2513 \mathrm{~cm}^{-1}$ arose due to combination $\left(v_{1}+v_{3}\right)$ modes of bulk calcite. The band at 1796 $\mathrm{cm}^{-1}$ was a further combination mode $\left(v_{1}+v_{2}\right)$ of bulk carbonate. Collectively these bands were taken as an indication of significant formation of bulk carbonate, beyond previously observed surface carbonate species or indicating diffusion of carbonate species into the bulk crystal lattice. Assignments were made on the basis of previous investigations (Neagle and Rochester, 1990; Schroed et al., 1962). With sample at 500 and $600^{\circ} \mathrm{C}$, all of the discussed bands increased in intensity. In subsequent isothermal investigations at 400 (Figure $6 \mathrm{~b}$ ) and $350{ }^{\circ} \mathrm{C}$ (Figure 6c) bulk vibrational modes were monitored temporally. Bands in the $3000-2400 \mathrm{~cm}^{-1}$ range increased in intensity throughout, with the $1796 \mathrm{~cm}^{-1}$ absorption band (not shown) displaying similar behaviour in agreement with the relationship evidenced in Figure 6a.
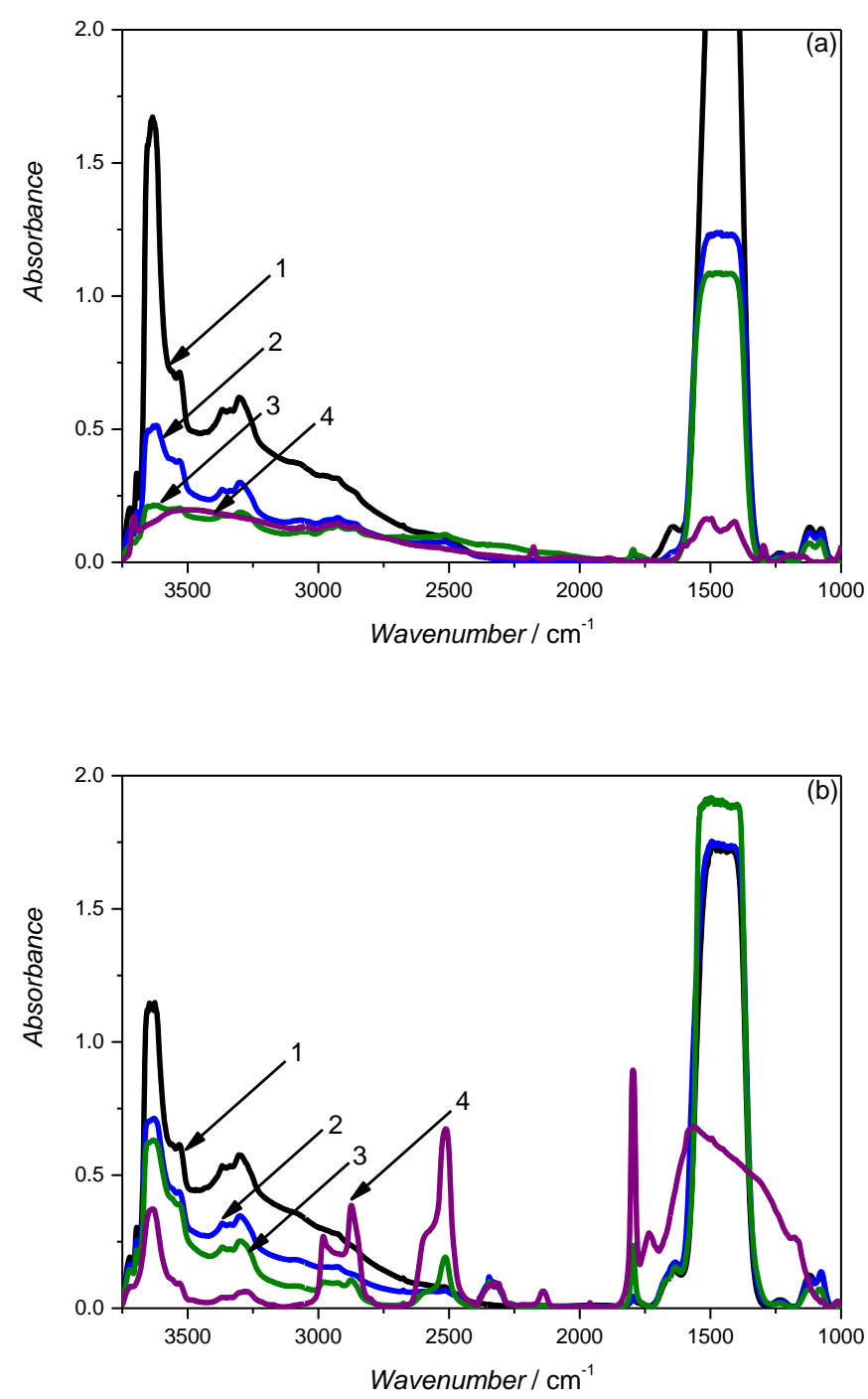
Figure 7 - FTIR spectra of (a) calcination of $\mathrm{Ca}(\mathrm{OH})_{2}$ in-vacuo at room temperature (1), $100(2), 300$ (3) and $600{ }^{\circ} \mathrm{C}(4)$ and (b) carbonation of $\mathrm{Ca}(\mathrm{OH})_{2}$ in the presence of 50 Torr of $\mathrm{CO}_{2}$ at room temperature (1), 100 (2), 300 (3) and $600{ }^{\circ} \mathrm{C}(4)$.

For ease of interpretation, a selection of raw experimental spectra (i.e. not difference spectra) are shown of $\mathrm{Ca}(\mathrm{OH})_{2}$ being heated in-vacuo (Figure 7a) and in the presence of 50 Torr of $\mathrm{CO}_{2}$ (Figure 7b). The associated difference spectra are given (Supplementary Information, S3a \& b). Bands across a broad range $(3750-3250 \mathrm{~cm}$ $\left.{ }^{1}\right)$ assigned to a variety of hydroxyl functionalities on the $\mathrm{Ca}(\mathrm{OH})_{2}$ surface decreased in intensity with heating invacuo (Figure 7a) and to a lesser extent under $\mathrm{CO}_{2}$ (Figure 7b). Free $\mathrm{OH}\left(3707 \mathrm{~cm}^{-1}\right)$ remained on the surface of $\mathrm{Ca}(\mathrm{OH})_{2}$ at $600{ }^{\circ} \mathrm{C}$ in-vacuo with a small broad band also present towards lower wavenumbers. At all temperatures in $\mathrm{CO}_{2}$, a larger number and variety of $\mathrm{OH}$ functionality remained in the $3750-3250 \mathrm{~cm}^{-1}$ range. Strong absorptions in the range ascribed to surface carbonate species as discussed above $\left(1750-1000 \mathrm{~cm}^{-1}\right)$, present due to reaction in air prior to experiment were also observed throughout (Figure 7), broadening at high temperature in the presence of $\mathrm{CO}_{2}$ (Figure $7 \mathrm{~b}$ ). For the first time, bicarbonate species were observed (1750 and $1250 \mathrm{~cm}^{-1}$ ) with sample at $600^{\circ} \mathrm{C}$ (Figure $7 \mathrm{~b}$ ), in part accounting for the broadening of the carbonate species band. Furthermore a band at ca. $1630 \mathrm{~cm}^{-1}$ present only in-vacuo at RT in Figure 7a remained present at 300 and $600^{\circ} \mathrm{C}$ in the presence of $\mathrm{CO}_{2}$ (Figure 7b). Due to the lack of transmission in the region where maxima due to surface carbonate bands are expected $\left(1750-1000 \mathrm{~cm}^{-1}\right)$, absorption intensity is not representative of carbonate amount, as upon transformation infinite absorbance would be obtained. Therefore changes in intensity cannot be understood in terms of calcination or carbonation, only presence. The appearance of bands due to bulk carbonates $\left(2980,2875,2580,2513\right.$ and $1796 \mathrm{~cm}^{-1}$ ) occurred at $300^{\circ} \mathrm{C}$ in the presence of $\mathrm{CO}_{2}($ Figure $7 \mathrm{~b} \&$ Supplementary Information, S3b). A small band due to gaseous $\mathrm{CO}_{2}$ at $2350 \mathrm{~cm}^{-1}$ was also observed, not changing in intensity, indicating the overpressure was sufficient for carbonation reaction.

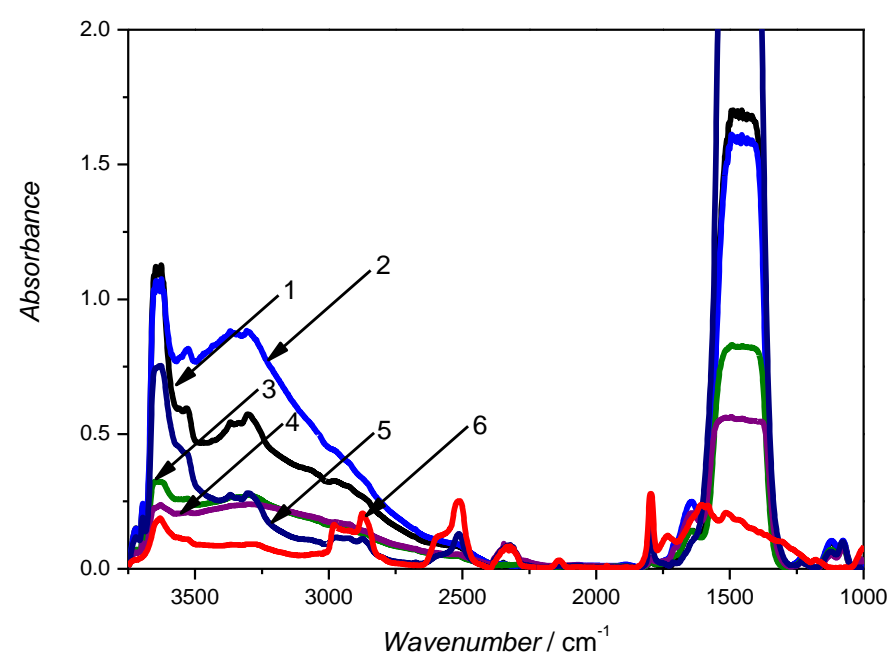

Figure 8 - FTIR spectra of $\mathrm{Ca}(\mathrm{OH})_{2}(1)$ exposed to $\mathrm{H}_{2} \mathrm{O}$ at room temperature (2), heated at $100{ }^{\circ} \mathrm{C}(3)$ and subsequent carbonationof $\mathrm{Ca}(\mathrm{OH})_{2}$ in the presence of 50 Torr of $\mathrm{CO}_{2}$ at $100(4), 300(5)$ and $600{ }^{\circ} \mathrm{C}(6)$.

$\mathrm{Ca}(\mathrm{OH})_{2}$ was exposed to water vapour ( $15 \mathrm{Torr}$ ), followed by heating to $100^{\circ} \mathrm{C}$ and subsequent $\mathrm{CO}_{2}$ exposure in an effort to simulate the presence of steam during carbonation (Figure 8). Again spectra shown are a selection of raw experimental data. The full experimental spectral set is given in Supplementary Information, S4. In the initial 
wetting stage, bands due to hydroxyl groups $\left(3750-3250 \mathrm{~cm}^{-1}\right)$ and molecularly adsorbed water $\left(1630 \mathrm{~cm}^{-1}\right)$ increased relative to initial $\mathrm{Ca}(\mathrm{OH})_{2}$. Upon heating both sets of band decreased in intensity. Upon exposure to $\mathrm{CO}_{2}$ and heating, bands due to bulk carbonate species (2980, 2875, 2580, 2513 and $1796 \mathrm{~cm}^{-1}$ ) appeared welldefined in spectra of sample at $300^{\circ} \mathrm{C}$ and continued to increase in intensity with increasing temperature. Surface carbonate species $\left(1750-1000 \mathrm{~cm}^{-1}\right)$ were also present in large quantities. Again bands due to bicarbonate surface species were apparent at high temperature (1750 and $1250 \mathrm{~cm}^{-1}$ ) (Busca and Lorenzelli, 1982).

\section{$3.3 \mathrm{CO}_{2}$ Gravimetric Adsorption}

$\mathrm{CO}_{2}$ adsorption on $\mathrm{CaO}$ under isothermal conditions (Figure 9a) displayed the typical dual regime behaviour widely observed for the carbonation reaction. Conversion (Figure 9) was shown as normalised relative to a 10 min (100 data points) stabilisation period in each experiment. A repeatability investigation was conducted on $\mathrm{CaO}$ at $400^{\circ} \mathrm{C}$ (Supplementary Information, S5) to represent an intermediate temperature where significant conversion would occur. To determine "fast" $\left(f_{c}\right)$ and "slow" $\left(s_{c}\right)$ conversion, first derivatives of conversion curves in Figure 9a were plotted. The change in regime was attributed as the point where the "slow" regime started, i.e. the inflexion point in the first derivative provided the "fast" conversion (Supplementary Information, S6). The final "slow" regime conversion was calculated as the numerical average during the final $10 \mathrm{~min}$ (100 data points) of the experiment. 

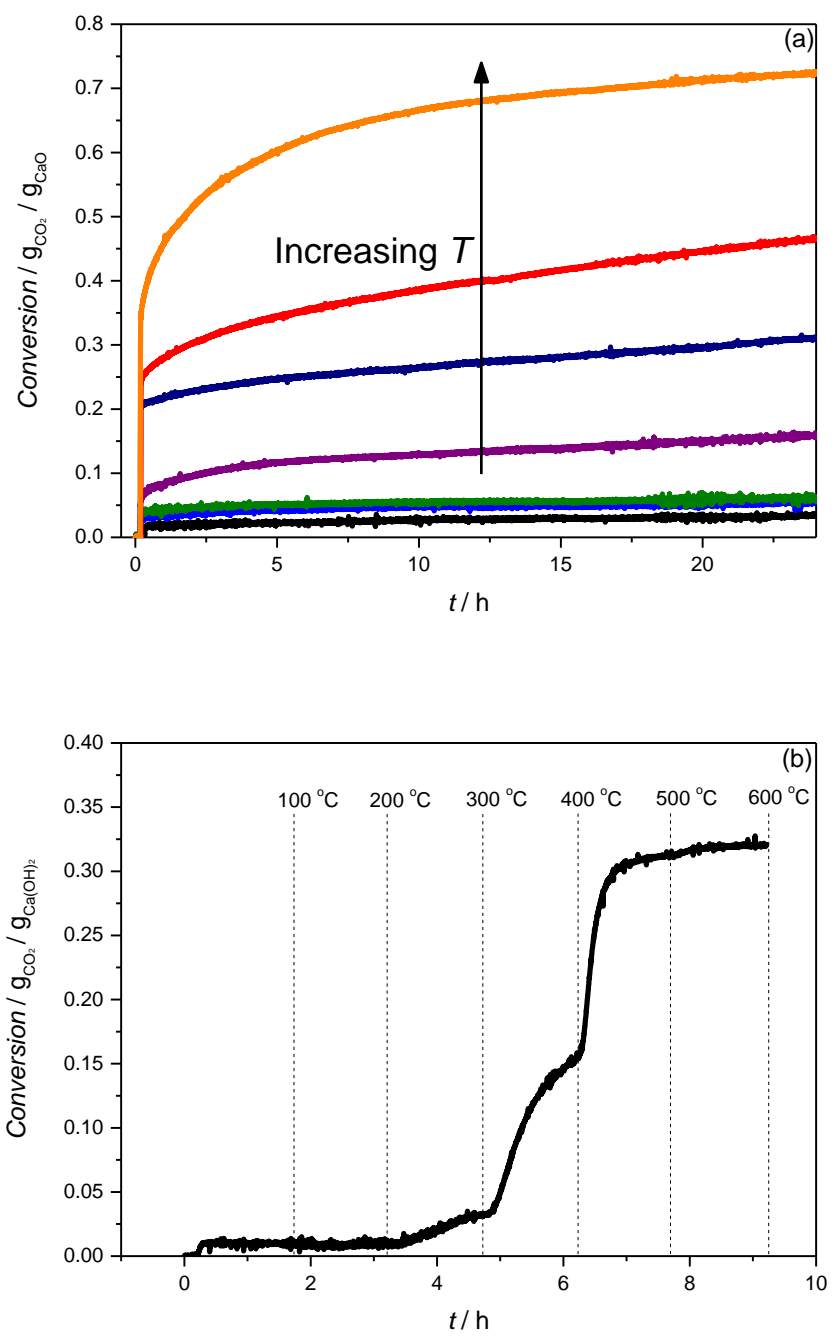

Figure 9-Gas-solid carbonation of (a) $\mathrm{CaO}$ from $\mathrm{Ca}(\mathrm{OH})_{2}$ under isothermal conditions at $\mathrm{RT}, 100,200,300,400,500$ and $600^{\circ} \mathrm{C}$ and $(\mathrm{b})$ $\mathrm{Ca}(\mathrm{OH})_{2}$ under non-isothermal conditions.

Values for $\mathrm{CaO}$ conversion in each regime and $\mathrm{Ca}(\mathrm{OH})_{2}$ final conversion are given in Table 2. Even though it was not possible to accurately determine the position of the first derivative in the room temperature conversion plot, the final "slow" conversion data has been left to aid subsequent discussion. Conversion was extremely low at low temperature (Table 2 ) until at $30^{\circ} \mathrm{C}$ final "slow" conversion $\left(s_{c}\right)$ values became appreciable, with "fast" conversion $\left(f_{c}\right)$ displaying a significant increase at $400^{\circ} \mathrm{C}$. 
Table 2 - Conversion in "fast" $\left(f_{c}\right)$ and "slow" $\left(s_{c}\right)$ regimes during $\mathrm{CaO}$ and $\mathrm{Ca}(\mathrm{OH})_{2}$ carbonation. Repeatability measurements (Supplementary Information, S5).

\begin{tabular}{llll}
$T$ & $f_{\mathrm{c}}$ & $s_{\mathrm{c}}$ & $s_{\mathrm{c}}$ \\
$\left({ }^{\circ} \mathrm{C}\right)$ & $\left(\mathrm{g} \mathrm{CO}_{2} / \mathrm{g} \mathrm{CaO}\right)$ & $\left(\mathrm{g} \mathrm{CO}_{2} / \mathrm{g} \mathrm{CaO}\right)$ & $\left(\mathrm{g} \mathrm{CO}_{2} / \mathrm{g} \mathrm{Ca}(\mathrm{OH})_{2}\right)$ \\
\hline $\mathrm{RT}$ & $\mathrm{xxx}$ & 0.03 & 0.01 \\
100 & 0.02 & 0.05 & 0.01 \\
200 & 0.03 & 0.06 & 0.01 \\
300 & 0.04 & 0.16 & 0.03 \\
400 & 0.20 & 0.31 & 0.15 \\
500 & 0.24 & 0.47 & 0.31 \\
600 & 0.27 & 0.72 & 0.32 \\
\hline
\end{tabular}

\section{Discussion}

X-ray diffraction (Figure 2) confirmed materials permitted differentiation between $\mathrm{Ca}(\mathrm{OH})_{2}$ and $\mathrm{CaCO}_{3}$ derived $\mathrm{CaO}$. Analysis of textural properties (Table 1 ) indicated that upon calcination of $\mathrm{Ca}(\mathrm{OH})_{2}$ surface area increased as well as a reduction in average pore width. It was previously observed that after an initial sharp increase in surface area following treatment around $400^{\circ} \mathrm{C}$, sintering began lowering surface area to a value still higher than initial $\mathrm{Ca}(\mathrm{OH})_{2}$ (Irabien et al., 1990). It was therefore likely that the $\mathrm{Ca}(\mathrm{OH})_{2}$ calcination treatment sintered the produced $\mathrm{CaO}$ to a significant degree, but that these conditions were representative of those found in the real $\mathrm{CaL}$ process, at least in terms of temperature. For $\mathrm{CaCO}_{3}$ and $\mathrm{CaO}$ there was a good correlation between crystallite size and surface area. However for $\mathrm{Ca}(\mathrm{OH})_{2}$ the crystallite size and surface area discontinuity could be explained by lower porosity as compared to the former samples. It also must be remembered that Scherrer analysis provides size with respect to one crystalline facet, the most populous but not necessarily the largest, and also assumes a specific shape factor. However, it was confirmed that all samples were nanosized and thus suitable for transmission FTIR investigation.

The formation of surface carbonates (Figure 3) occurred in an identical manner in simulated first and second loops, in terms of carbonate coordination (monodentate) after carbonation on freshly calcined $\mathrm{Ca}(\mathrm{OH})_{2}$ (Figure $3 a$ ) and in the first loop (Figure $3 \mathrm{~b}$ ). It should be remembered that $\mathrm{CO}_{2}$ is a fairly insensitive probe molecule with the potential to miss subtle changes to sites of low population. However, as the main reactant of interest, it suggested that no significantly appreciable changes in reactivity occurred, in the cycle where the drop in conversion is the most pronounced and therefore most likely to display reactivity differences. Furthermore $\mathrm{CO}_{2}$ adsorption on $\mathrm{CaO}$ at RT displayed a final "slow" conversion (24 h) of $0.03 \mathrm{gCO}_{2} / \mathrm{gCaO}$ (Table 2) which equated to $65.2 \%$ surface coverage (Supplementary Information, S7). The lack of bulk carbonate band formation in this regime showed that carbonate formation was limited to the surface layer at low temperature. In the "fast" regime, surface coverage was below $100 \%$ for $300^{\circ} \mathrm{C}$ and below, with a significant jump at $400^{\circ} \mathrm{C}$ to $435 \%$ surface coverage i.e. considerable bulk carbonate formation in the "fast" reaction regime (Figure 10). The appearance of FTIR bands due to bulk modes for sample at $400{ }^{\circ} \mathrm{C}$ (Figure 6a) and the rapid growth of those bands at $400^{\circ} \mathrm{C}$ (Figure $6 \mathrm{~b}$ ) supported this observation. At $300^{\circ} \mathrm{C}$ surface coverage was $87.0 \%$ and thus the lack of bulk modes on 
$\mathrm{CaO}$ (Figure 6a) at this temperature was in agreement with the gravimetric investigation. Below $300^{\circ} \mathrm{C}, \mathrm{CO}_{2}$ adsorption on $\mathrm{CaO}$ is limited to the surface, with bulk carbonate formation increasing with temperature above this (Cazorla-Amoros et al., 1991). Furthermore bands due to vibrational modes of bulk carbonate were always preceded by intense absorption maxima due to surface species, confirming the dual reaction regime spectroscopically. At the highest temperatures studied, both $\mathrm{CaO}$ and $\mathrm{Ca}(\mathrm{OH})_{2}$ approached the theoretical conversion limits (Figure 10). The distinction between surface and bulk carbonation becomes futile at $400^{\circ} \mathrm{C}$ and above where both surface and bulk carbonation are occurring at appreciable rates in the "fast" reaction regime.

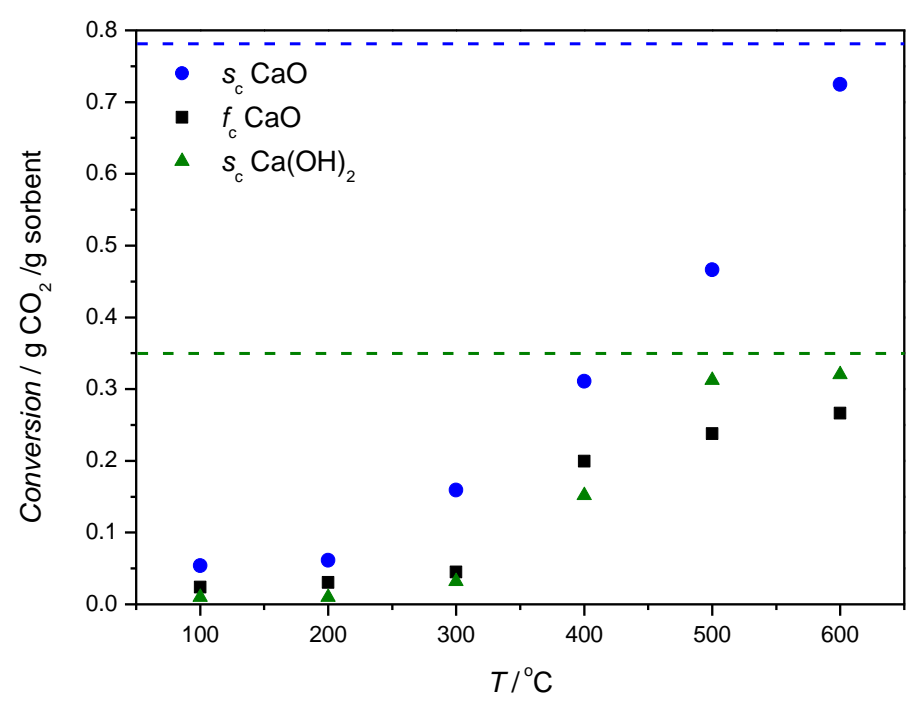

Figure 10 - "Slow" conversion $\left(s_{c}\right)$ and "fast" conversion $\left(f_{c}\right)$ versus carbonation temperature. Dashed lines indicate theoretical conversion limit of $0.35 \mathrm{~g} \mathrm{CO}_{2} / \mathrm{g} \mathrm{Ca}(\mathrm{OH})_{2}$ (lower dashed line) and $0.78 \mathrm{~g} \mathrm{CO}_{2} / \mathrm{g} \mathrm{CaO}$ (upper dashed line).

The adsorption of $\mathrm{D}_{2} \mathrm{O}$ provided greater information on the changes to the oxide surface, particularly with reference to adsorption history. Upon calcination of $\mathrm{Ca}(\mathrm{OH})_{2}$ highly reactive sites were exposed (Figure 4a) that were not present after carbonation and re-calcination (Figure 4c). The broadening below $2700 \mathrm{~cm}^{-1}$ was previously explained as indicative of the presence of defect $\mathrm{O}^{2-}$ sites. As the distance between "free" deuteroxide species is too great for hydrogen bonding to occur, there should be intermittent defects to facilitate hydrogen bonding induced broadening of the band due to the $\mathrm{OH}$ or OD stretching mode (Low et al., 1971). Therefore the presence of broadening indicates the formation of highly reactive surface sites when $\mathrm{Ca}(\mathrm{OH})_{2}$ is calcined. Furthermore, this effect was confirmed in spectra of $\mathrm{D}_{2} \mathrm{O}$ adsorption on $\mathrm{CaO}$ produced from $\mathrm{Ca}(\mathrm{OH})_{2}$ and $\mathrm{CaCO}_{3}$ (Figure 5), which again showed that there were more highly reactive sites on the oxide produced from $\mathrm{Ca}(\mathrm{OH})_{2}$. It would appear that the presence of carbonates, either as bulk calcite or simply adsorbed surface carbonates, limit the formation of highly reactive sites during subsequent calcination.

The formation of active sites due to water vapour adsorption on $\mathrm{CaO}$ produced from $\mathrm{Ca}(\mathrm{OH})_{2}$ has been observed previously (Beruto et al., 1983) and could be an indication, confirmed here, that in part explains the increased reactivity observed following hydration reactivation. Subsequent formation of carbonate on the surface following $\mathrm{D}_{2} \mathrm{O}$ exposure (Figure $4 \mathrm{~b}, \mathrm{~d}$ ) displayed a shift in the band at 1476 to $1487 \mathrm{~cm}^{-1}$ and an increase in 
intensity. Generally bands in the carbonate region showed lower intensity for the same $\mathrm{CO}_{2}$ exposure pressures, highlighting that adsorbed $\mathrm{D}_{2} \mathrm{O}$ was occupying the identified active sites. On $\mathrm{CaO}(100)$ it has been shown by semiempirical atomistic simulations that at low partial pressures of water, coadsorption of water occurs in a dissociative manner resulting in a decrease in the number of adsorbed carbonate species (Allen et al., 2009). The shift and increase in intensity was likely due to interaction between adsorbed deuteroxide and carbonate species. Considering that both "free" and "bound" deuteroxide species were present on the surface, and the surface structure of $\mathrm{CaO}(100)$, two explanations can be proposed for the change in intensity. Either "free" deuteroxide species perturbed the carbonate species (asymmetric vibration of the upwards C-O), or "bound" deuteroxide perturbed the carbonate species (same vibration of the downwards C-O) (Scheme 2). Overall this would imply that the calcination of $\mathrm{Ca}(\mathrm{OH})_{2}$ to produce $\mathrm{CaO}$ provides highly reactive sites but that the presence of water $\left(D_{2} O\right)$ on the surface occupies these sites at low temperature and perturbs the structure of the formed surface carbonates.
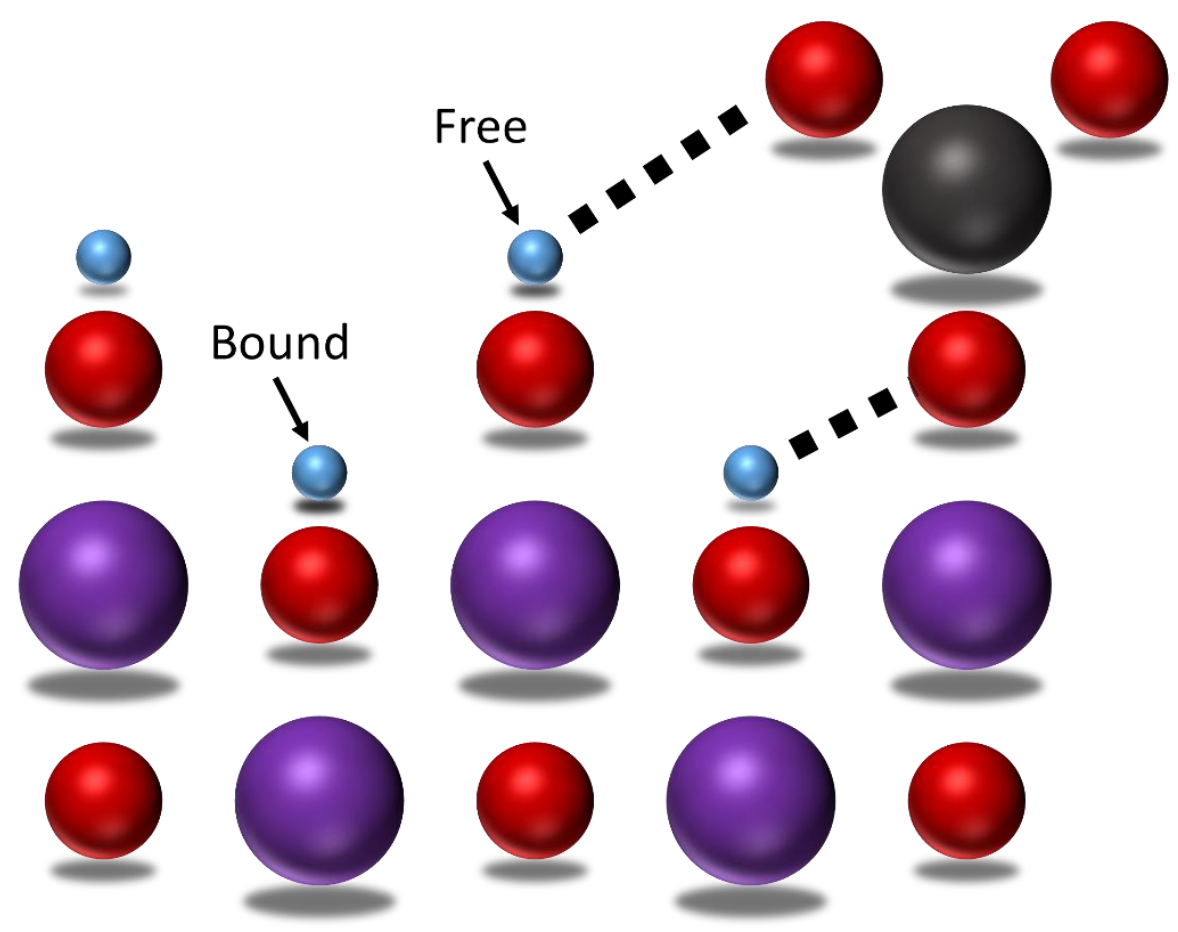

Scheme 2 - Potential hydrogen bond interactions between "bound" or "free" hydroxyl groups and surface carbonate. 0 - red spheres, $\mathrm{Ca}$ - purple spheres, D - blue spheres, C - black sphere.

Decomposition of $\mathrm{Ca}(\mathrm{OH})_{2}$ in-vacuo (Figure 7a) resulted in the removal of a wide variety of hydroxyl functionality. In the presence of $\mathrm{CO}_{2}$ (Figure $7 \mathrm{~b}$ ) hydroxyl groups and undissociated molecular water were retained until relatively higher temperatures. Bands due to bulk carbonate were observed at $300^{\circ} \mathrm{C}$ (Figure $7 \mathrm{~b}-$ green spectrum), lower than the corresponding carbonation of $\mathrm{CaO}$ where no well-defined bands were observed at $300^{\circ} \mathrm{C}$ (Figure $6 \mathrm{a}$ - black spectrum). Together these results would suggest that bulk carbonate species were forming at lower temperatures when $\mathrm{Ca}(\mathrm{OH})_{2}$ was directly carbonated and that water was being produced, consistent with simple mechanistic consideration and previous investigations (Montes-Hernandez et al., 2010). 
Furthermore it has previously been observed that the presence of water encourages diffusion to the bulk of carbonating particles (Manovic and Anthony, 2010), consistent with spectroscopic observations here. The presence of molecular water $\left(1630 \mathrm{~cm}^{-1}\right)$ and hydroxyl functionality $\left(3750-3250 \mathrm{~cm}^{-1}\right)$ during direct carbonation (Figure 7b) supports findings (Materic and Smedley, 2011) whereby the carbonation reaction proceeds via an adsorbed water film on the surface. Furthermore, the presence of molecular water on the surface can somewhat confirm previous findings, whereby water molecules departing the $\mathrm{Ca}(\mathrm{OH})_{2}$ lattice act as a liquid-like interface for $\mathrm{H}_{2} \mathrm{O}$ and $\mathrm{CO}_{2}$ to be exchanged (Materic et al., 2015). The identification of bicarbonate species (Figure 7b \& Figure 8) provides further support for this hypothesis.

The discontinuity between the spectroscopic and gravimetric investigations deserves further consideration. Considering the spectroscopic data where vibrational modes due to bulk carbonate are evidenced at $300^{\circ} \mathrm{C}$ on $\mathrm{Ca}(\mathrm{OH})_{2}$ compared to $400{ }^{\circ} \mathrm{C}$ on $\mathrm{CaO}$, one would expect conversion of $\mathrm{Ca}(\mathrm{OH})_{2}$ at $300^{\circ} \mathrm{C}$ to exceed that of $\mathrm{CaO}$ at $400^{\circ} \mathrm{C}$. However in the gravimetric experiments (Figure 10) final "slow" conversion value (as a percentage of the theoretical limit) for $\mathrm{CaO}$ at $400^{\circ} \mathrm{C}$ is $\mathrm{ca} .20 \%$ and for $\mathrm{Ca}(\mathrm{OH})_{2}$ at $300^{\circ} \mathrm{C}$ is $\mathrm{ca}$. $8 \%$, in disagreement with the spectroscopic findings, if one assumes a direct relationship between bulk carbonate absorption and "slow" conversion. First the conversion value for $\mathrm{Ca}(\mathrm{OH})_{2}$ may be lower than expected due to simultaneous decomposition of $\mathrm{Ca}(\mathrm{OH})_{2}$. Previously it was shown for $\mathrm{Ca}(\mathrm{OH})_{2}$ powder heated under $\mathrm{N}_{2}$ or $\mathrm{CO}_{2}$ in separate experiments, decomposition and carbonation occurred respectively around $400{ }^{\circ} \mathrm{C}$ (Blamey et al., 2011). The observed molecular water $\left(1630 \mathrm{~cm}^{-1}\right)$ and the reduction in the intensity around $<3750 \mathrm{~cm}^{-1}$ (Figure $7 \mathrm{~b}$ ) would suggest that decomposition of $\mathrm{Ca}(\mathrm{OH})_{2}$ was occurring at the same time as carbonation. The water observed on the surface has been previously shown by infrared spectroscopy to increase in direct proportion with carbonate conversion, although at low temperature (Montes-Hernandez et al., 2010). Furthermore considering the ca. 50\% lower surface area of $\mathrm{Ca}(\mathrm{OH})_{2}$ it is reasonable to assume that surface coverage is complete at lower overall conversion values and thus bulk diffusion begins at lower overall conversion, enhanced by water on the surface. An alternative scenario would be that three dimensional structures with bulk-like vibrational properties form on the surface, but considering the findings of (Blamey et al., 2011) where $\mathrm{Ca}(\mathrm{OH})_{2}$ powder could not form a carbonate product layer, this seems unlikely. However, this scenario cannot be ruled out entirely as the mass change for a single carbonate layer on such small particles would be difficult to detect by their method.

\section{Conclusions}

Infrared spectroscopy was utilised to distinguish carbonate formation in the "fast" and "slow" reaction regimes with attention paid to surface chemistry of sorbents. Through probe molecule investigations of calcium looping sorbents under high vacuum conditions it was shown that:

1) $\mathrm{CaO}$ produced from $\mathrm{Ca}(\mathrm{OH})_{2}$ presented highly reactive surface sites, probably $\mathrm{O}^{2-}$, even in a regime where sintering was encouraged.

2) When $\mathrm{CaO}$ produced from $\mathrm{Ca}(\mathrm{OH})_{2}$ was subsequently carbonated and calcined these active sites were reduced in number. The same behaviour was observed when $\mathrm{CaCO}_{3}$ was used as a source of $\mathrm{CaO}$ indicating 
that adsorption history, particularly the presence of carbonates, influences the available sites on calcined sorbents.

3) The presence of water $\left(D_{2} O\right)$ occupied highly reactive sites and perturbed surface carbonates formed on $\mathrm{CaO}$ at low temperature.

4) The presence of water or hydroxyl functionality on the surface of $\mathrm{Ca}(\mathrm{OH})_{2}$ initiated the formation of bulk carbonate species at lower temperatures than on $\mathrm{CaO}$.

The results highlight the subtleties associated with the impact of water in calcium looping and provide fundamental molecular observations of use in explaining the impacts of water during bench and pilot scale testing. Infrared spectroscopy could be explored further in terms of calcium looping through the application of highly sensitive probe molecules to investigate crystalline facets known to be of significant importance for high temperature adsorption, i.e. $\mathrm{CaO}$ (111). Furthermore the investigation of highly cycled sorbents which may display a reduction in the prevalence of the (111) facet could provide experimental evidence for an issue hinted at computationally (Besson and Favergeon, 2013). The use of quantitative FTIR spectroscopy (McCue et al., 2015) could permit the determination of diffusion rates of carbonate species assuming a suitable absorption coefficient could be determined. Currently the temperature limitation of our apparatus does not permit high temperature calcination conditions and approaches the limitations of the cell at conditions where carbonate diffusion becomes appreciable.

\section{Acknowledgements}

The Engineering and Physical Sciences Research Council (EPSRC) is gratefully acknowledged for a Doctoral Training Grant for G.A.M. (EP/K0502960/1). Mr. C. McRitchie (Surface Chemistry and Catalysis Group, University of Aberdeen) is thanked for useful discussion.

\section{References}

Abad, A., Abanades, J.C., Adánez, J., Alonso, M., Anthony, E.J., Arai, Y., Arias, B., Bidwe, A.R., Blamey, J., BootHandford, M., Broda, M., Butler, J.W., Chen, X., Diego, M.E., Dieter, H., Fennell, P., Florin, N., Grace, J.R., Kierzkowska, A.M., Lara, Y., Linderholm, C., Lisbona, P., Lyngfelt, A., Martínez, I., Martínez, A., Müller, C.R., Pröll, T., Romeo, L.M., Rydén, M., Scheffknecht, G., Yao, J.G., Zhao, C., Zhao, C., 2015. Calcium and Chemical Looping Technology for Power Generation and Carbon Dioxide $\left(\mathrm{CO}_{2}\right)$ Capture, Calcium and Chemical Looping Technology for Power Generation and Carbon Dioxide $\left(\mathrm{CO}_{2}\right)$ Capture. Elsevier. doi:10.1016/B978-0-85709-2434.01002-8

Abanades, J.C., 2002. The maximum capture efficiency of $\mathrm{CO}_{2}$ using a carbonation/calcination cycle of $\mathrm{CaO} / \mathrm{CaCO}_{3}$. Chem. Eng. J. 90, 303-306. doi:10.1021/ie0606946

Al-jeboori, M.J., Fennell, P.S., Nguyen, M., Feng, K., 2012. Effects of Different Dopants and Doping Procedures on the Reactivity of CaO-based Sorbents for $\mathrm{CO}_{2}$ Capture. Energy \& Fuels 26, 6584-6594. doi:10.1021/ef301153b

Al-jeboori, M.J., Nguyen, M., Dean, C., Fennell, P.S., 2013. Improvement of Limestone-Based $\mathrm{CO}_{2}$ Sorbents for $\mathrm{Ca}$ Looping by HBr and Other Mineral Acids. Ind. Eng. Chem. Res. 52, 1426-1433. doi:10.1021/ie302198g

Allen, J.P., Parker, S.C., Price, D.W., 2009. Atomistic Simulation of the Surface Carbonation of Calcium and Magnesium Oxide Surfaces. J. Phys. Chem. C 116, 8320-8328. doi:10.1021/jp303301q

Alvarez, D., Abanades, J.C., 2005. Determination of the critical product layer thickness in the reaction of $\mathrm{CaO}$ with 
$\mathrm{CO}_{2}$. Ind. Eng. Chem. Res. 44, 5608-5615. doi:10.1021/ie050305s

Anderson, J. a., Rochester, C.H., 1986. Infrared studies of probe molecules adsorbed on calcium oxide. J. Chem. Soc. Faraday Trans. 1 Phys. Chem. Condens. Phases 82, 1911-1922. doi:10.1039/f19868201911

Antzara, A., Heracleous, E., Lemonidou, A.A., 2015. Improving the stability of synthetic CaO-based $\mathrm{CO}_{2}$ sorbents by structural promoters. Appl. Energy 156, 331-343. doi:10.1016/j.apenergy.2015.07.026

Arias, B., Diego, M.E., Abanades, J.C., Lorenzo, M., Diaz, L., Martinez, D., Alvarez, J., Sanchez-Biezma, A., 2013. Demonstration of steady state $\mathrm{CO}_{2}$ capture in a $1.7 \mathrm{MW}_{\text {th }}$ calcium looping pilot. Int. J. Greenh. Gas Control 18 , 237-245. doi:10.1016/j.ijggc.2013.07.014

Arias, B., Grasa, G.S., Alonso, M., Abanades, J.C., 2012. Post-combustion calcium looping process with a highly stable sorbent activity by recarbonation. Energy Environ. Sci. 5, 7353-7359. doi:10.1039/c2ee03008j

Barker, R., 1973. The Reversibility of the Reaction $\mathrm{CaCO}_{3} \leftrightarrow \mathrm{CaO}+\mathrm{CO}_{2}$. J. Appl. Chem. Biotechnol. 23, 733-742. doi:10.1002/jctb.5020231005

Barrett, E.P., Joyner, L.G., Halenda, P.P., 1951. The Determination of Pore Volume and Area Distributions in Porous Substances. I. Computations from Nitrogen Isotherms. J. Am. Chem. Soc. 73, 373-380. doi:10.1021/ja01145a126

Beruto, D., Spinolo, G., Barco, L., Tamburini, U.A., Belleri, G., 1983. On the nature of the crystallographic disorder in submicrometer particles of $\mathrm{Ca}(\mathrm{OH})_{2}$ produced by vapour phase hydration. Ceram. Int. 9, 22-25. doi:10.1016/0272-8842(83)90006-8

Besson, R., Favergeon, L., 2013. Atomic-Scale Study of Calcite Nucleation in Calcium Oxide. J. Phys. Chem. C 117, 8813-8821. doi:10.1021/jp4002252

Blamey, J., Al-Jeboori, M.J., Manovic, V., Fennell, P.S., Anthony, E.J., 2016. $\mathrm{CO}_{2}$ capture by calcium aluminate pellets in a small fluidized bed. Fuel Process. Technol. 142, 100-106. doi:10.1016/j.fuproc.2015.09.015

Blamey, J., Anthony, E.J., Wang, J., Fennell, P.S., 2010. The calcium looping cycle for large-scale $\mathrm{CO}_{2}$ capture. Prog. Energy Combust. Sci. 36, 260-279. doi:10.1016/j.pecs.2009.10.001

Blamey, J., Lu, D.Y., Fennell, P.S., Anthony, E.J., 2011. Reactivation of CaO-Based Sorbents for $\mathrm{CO}_{2}$ Capture : Mechanism for the Carbonation of $\mathrm{Ca}(\mathrm{OH})_{2}$. Ind. Eng. Chem. Res. 50, 10329-10334. doi:10.1021/ie200912s

Blamey, J., Zhao, M., Manovic, V., Anthony, E.J., Dugwell, D.R., Fennell, P.S., 2015. A Shrinking Core Model for Steam Hydration of CaO-Based Sorbents Cycled for $\mathrm{CO}_{2}$ Capture. Chem. Eng. J. 291, 298-305. doi:10.1016/j.cej.2016.01.086

Boot-Handford, M.E., Abanades, J.C., Anthony, E.J., Blunt, M.J., Brandani, S., Mac Dowell, N., Fernández, J.R., Ferrari, M.-C., Gross, R., Hallett, J.P., Haszeldine, R.S., Heptonstall, P., Lyngfelt, A., Makuch, Z., Mangano, E., Porter, R.T.J., Pourkashanian, M., Rochelle, G.T., Shah, N., Yao, J.G., Fennell, P.S., 2014. Carbon capture and storage update. Energy Environ. Sci. 7, 130. doi:10.1039/c3ee42350f

Borgwardt, R.H., 1989. Sintering of nascent calcium oxide. Chem. Eng. Sci. 44, 53-60. doi:10.1016/00092509(89)85232-7

Broda, M., Kierzkowska, A.M., Müller, C.R., 2012. Influence of the calcination and carbonation conditions on the $\mathrm{CO}_{2}$ uptake of synthetic Ca-based $\mathrm{CO}_{2}$ sorbents. Environ. Sci. Technol. 46, 10849-10856. doi:10.1021/es302757e

Broda, M., Müller, C.R., 2014. Sol-gel-derived, CaO-based, $\mathrm{ZrO}_{2}$-stabilized $\mathrm{CO}_{2}$ sorbents. Fuel 127, 94-100. doi:10.1016/j.fuel.2013.08.004

Brunauer, S., Emmet, P.H., Teller, E., 1938. Adsorption of Gases in Multimolecular Layers. J. Am. Chem. Soc. 60, 309319. doi:10.1021/ja01269a023

Busca, G., Lorenzelli, V., 1982. Infrared spectroscopic identification of species arising from reactive adsorption of carbon oxides on metal oxide surfaces. Mater. Chem. 7, 89-126. doi:10.1016/0390-6035(82)90059-1

Cazorla-Amoros, D., Joly, J.P., Linares-Solano, A., Marcilla-Gomis, A., Salinas-Martinez de Lecea, C., 1991. CO2-CaO Surface and Bulk Reactions: Thermodynamic and Kinetic Approach. J. Phys. Chem 6611-6617. doi:10.1021/j100170a043

Champagne, S., Lu, D., Symonds, R., Macchi, A., Anthony, E.J., 2015. The Effect of Steam Addition to the Calciner in a 
Calcium Looping Pilot Plant. Powder Technol. doi:10.1016/j.powtec.2015.07.039

Chang, M., Chen, W., Huang, C., Liu, W., Chang, W., Chen, W., Cheng, J., Huang, K., Hsu, H., 2014. Design and Experimental Testing of a $1.9 \mathrm{MW}_{\text {th }}$ Calcium Looping Pilot Plant. Energy Procedia 63, 2100-2108. doi:10.1016/j.egypro.2014.11.226

Chen, Z., Song, H.S., Portillo, M., Lim, C.J., Grace, J.R., Anthony, E.J., 2009. Long-term calcination/carbonation cycling and thermal pretreatment for $\mathrm{CO}_{2}$ capture by limestone and dolomite. Energy and Fuels 23, 1437-1444. doi:10.1021/ef800779k

Clough, P.T., Boot-handford, M.E., Zhao, M., Fennell, P.S., 2016. Degradation study of a novel polymorphic sorbent under realistic post-combustion conditions. Fuel 186, 708-713. doi:10.1016/j.fuel.2016.08.098

Coppola, A., Palladino, L., Montagnaro, F., Scala, F., Salatino, P., 2015. Reactivation by Steam Hydration of Sorbents for Fluidized-Bed Calcium Looping. Energy \& Fuels 29, 4436-4446. doi:10.1021/acs.energyfuels.5b00413

Coppola, A., Salatino, P., Montagnaro, F., Scala, F., 2014. Reactivation by water hydration of the $\mathrm{CO}_{2}$ capture capacity of a calcium looping sorbent. Fuel 127, 109-115. doi:10.1016/j.fuel.2013.09.059

Dean, C.C., Blamey, J., Florin, N.H., Al-Jeboori, M.J., Fennell, P.S., 2011. The calcium looping cycle for $\mathrm{CO}_{2} \mathrm{capture}$ from power generation, cement manufacture and hydrogen production. Chem. Eng. Res. Des. 89, 836-855. doi:10.1016/j.cherd.2010.10.013

Diego, M.E., Arias, B., Méndez, A., Lorenzo, M., Díaz, L., Sánchez-Biezma, A., Abanades, J.C., 2016. Experimental testing of a sorbent reactivation process in La Pereda $1.7 \mathrm{MW}_{\text {th }}$ calcium looping pilot plant. Int. J. Greenh. Gas Control 50, 14-22. doi:10.1016/j.jjggc.2016.04.008

Donat, F., Florin, N.H., Anthony, E.J., Fennell, P.S., 2012. Influence of High-Temperature Steam on the Reactivity of $\mathrm{CaO}$ Sorbent for $\mathrm{CO}_{2}$ Capture. Environ. Sci. Technol. 46, 1262-1269. doi:10.1021/es202679w

Erans, M., Manovic, V., Anthony, E.J., 2016. Calcium looping sorbents for $\mathrm{CO}_{2}$ capture. Appl. Energy 180, 722-742. doi:10.1016/j.apenergy.2016.07.074

Filitz, R., Kierzkowska, A.M., Broda, M., Müller, C.R., 2012. Highly efficient $\mathrm{CO}_{2}$ sorbents: development of synthetic, calcium-rich dolomites. Environ. Sci. Technol. 46, 559-65. doi:10.1021/es2034697

Gonza, B., Grasa, G., Murillo, R., Abanades, J.C., Alonso, M., Rodrı, N., 2010. Carbon dioxide capture from combustion flue gases with a calcium oxide chemical loop. Experimental results and process development. Int. J. Greenh. Gas Control 4, 167-173. doi:10.1016/j.ijggc.2009.10.004

González, B., Blamey, J., Al-Jeboori, M.J., Florin, N.H., Clough, P.T., Fennell, P.S., 2015. Additive effects of steam addition and $\mathrm{HBr}$ doping for $\mathrm{CaO}-$ based sorbents for $\mathrm{CO}_{2}$ capture. Chem. Eng. Process. Process Intensif. doi:10.1016/j.cep.2015.09.019

Grasa, G.S., Abanades, J.C., 2006. $\mathrm{CO}_{2}$ Capture Capacity of $\mathrm{CaO}$ in Long Series of Carbonation/Calcination Cycles. Ind. Eng. Chem. Res. 45, 8846-8851. doi:10.1021/ie0606946

Hanak, D.P., Kolios, A.J., Manovic, V., 2016. Comparison of probabilistic performance of calcium looping and chemical solvent scrubbing retrofits for $\mathrm{CO}_{2}$ capture from coal-fired power plant. Appl. Energy 172, 323-336. doi:10.1016/j.apenergy.2016.03.102

Hanak, D.P., Manovic, V., 2015. Calcium looping with supercritical $\mathrm{CO}_{2}$ cycle for decarbonisation of coal-fired power plant. Energy Environ. Sci. Under revi, 971-983. doi:10.1039/C5EE02950C

Huang, C., Chang, K., Yu, C., Chiang, P., Wang, C., 2010. Development of high-temperature $\mathrm{CO}_{2}$ sorbents made of CaO-based mesoporous silica. Chem. Eng. J. 161, 129-135. doi:10.1016/j.cej.2010.04.045

Irabien, A., Viguri, J.R., Cortabitarte, F., Ortiz, I., 1990. Thermal Dehydration of Calcium Hydroxide. 2 . Surface Area Evolution. Ind. Eng. Chem. Res. 29, 1606-1611. doi:10.1021/ie00104a005

Li, Z., Cai, N., Huang, Y., Han, H., 2005. Synthesis, Experimental Studies, and Analysis of a New Calcium-Based Carbon Dioxide Absorbent. Energy \& Fuels 19, 1999-2004. doi:10.1021/ef0496799

Liu, W.G., Low, N.W.L., Feng, B., Wang, G., Diniz Da Costa, J.C., 2010. Calcium precursors for the production of CaO sorbents for multicycle $\mathrm{CO}_{2}$ capture. Environ. Sci. Technol. 44, 841-847. doi:10.1021/es902426n

Low, M.J.D., Takezawa, N., Goodsel, A.J., 1971. Infrared study of hydroxyls on active CaO. J. Colloid Interface Sci. 37, 
422-429. doi:10.1016/0021-9797(71)90310-9

Lu, D.Y., Hughes, R.W., Anthony, E.J., Manovic, V., 2009. Sintering and Reactivity of $\mathrm{CaCO}_{3}$-Based Sorbents for In Situ $\mathrm{CO}_{2}$ Capture in Fluidized Beds under Realistic Calcination Conditions 135, 404-410. doi:10.1061/(ASCE)EE.19437870.0000079

Lu, H., Khan, A., Pratsinis, S.E., Smirniotis, P.G., Zu, C.-, 2009. Flame-Made Durable Doped-CaO Nanosorbents for $\mathrm{CO}_{2}$ Capture 96, 1093-1100. doi:10.1021/ef8007882

Lysikov, A.I., Salanov, A.N., Okunev, A.G., 2007. Change of $\mathrm{CO}_{2}$ Carrying Capacity of CaO in Isothermal Recarbonation - Decomposition Cycles. Ind. Eng. Chem. Res. 46, 4633-4638. doi:10.1021/ie0702328

Manovic, V., Anthony, E.J., 2010. Carbonation of CaO-Based Sorbents Enhanced by Steam Addition. Ind. Eng. Chem. Res. 49, 9105-9110. doi:10.1021/ie101352s

Manovic, V., Anthony, E.J., 2009. Screening of Binders for Pelletization of CaO-Based Sorbents for $\mathrm{CO}_{2}$ Capture. Energy \& Fuels 23, 4797-4804. doi:10.1021/ef900266d

Manovic, V., Anthony, E.J., 2008. Thermal activation of CaO-based sorbent and self-reactivation during $\mathrm{CO}_{2} \mathrm{capture}$ looping cycles. Environ. Sci. Technol. 42, 4170-4174. doi:10.1021/es800152s

Manovic, V., Anthony, E.J., 2007. Steam reactivation of spent CaO-based sorbent for multiple $\mathrm{CO}_{2}$ capture cycles. Environ. Sci. Technol. 41, 1420-5. doi:10.1021/es0621344

Manovic, V., Charland, J., Blamey, J., Fennell, P.S., Lu, D.Y., Anthony, E.J., 2009. Influence of calcination conditions on carrying capacity of $\mathrm{CaO}-$ based sorbent in $\mathrm{CO}_{2}$ looping cycles. Fuel 88, 1893-1900. doi:10.1016/j.fuel.2009.04.012

Manovic, V., Fennell, P.S., Al-Jeboori, M.J., Anthony, E.J., 2013. Steam-enhanced calcium looping cycles with calcium aluminate pellets doped with bromides. Ind. Eng. Chem. Res. 52, 7677-7683. doi:10.1021/ie400197w

Materic, V., Edwards, S., Smedley, S.I., Holt, R., 2010. $\mathrm{Ca}(\mathrm{OH})_{2}$ superheating as a low-attrition steam reactivation method for $\mathrm{CaO}$ in calcium looping applications. Ind. Eng. Chem. Res. 49, 12429-12434. doi:10.1021/ie100265x

Materic, V., Hyland, M., Jones, M.I., Northover, B., 2014. High Temperature Carbonation of Ca(OH) 2 : The Effect of Particle Surface Area and Pore Volume. Ind. Eng. Chem. Res. 53, 2994-3000. doi:10.1021/ie403005s

Materic, V., Ingham, B., Holt, R., 2015. In situ synchrotron XRD investigation of the dehydration and high temperature carbonation of $\mathrm{Ca}(\mathrm{OH})_{2}$. CrystEngComm 17, 7306-7315. doi:10.1039/C5CE01379H

Materic, V., Smedley, S.I., 2011. High Temperature Carbonation of $\mathrm{Ca}(\mathrm{OH})_{2}$. Ind. Eng. Chem. Res. 50, 5927-5932. doi:10.1021/ie200367w

Materić, B. V, Sheppard, C., Smedley, S.I., 2010. Effect of repeated steam hydration reactivation on CaO-based sorbents for $\mathrm{CO}_{2}$ capture. Environ. Sci. Technol. 44, 9496-9501. doi:10.1021/es102623k

McCue, A.J., Mutch, G.A., McNab, A.I., Campbell, S., Anderson, J.A., 2015. Quantitative determination of surface species and adsorption sites using Infrared spectroscopy. Catal. Today 259, 19-26. doi:10.1016/j.cattod.2015.03.039

McNab, A.I., Heinze, T., McCue, A.J., Dionisi, D., Anderson, J.A., 2017. Quantification of hydrocarbon species on surfaces by combined microbalance-FTIR. Spectrochim. Acta Mol. Biomol. Spectrosc. 181, 65-72 doi:10.1016/j.saa.2017.03.030

Montes-Hernandez, G., Pommerol, A., Renard, F., Beck, P., Quirico, E., Brissaud, O., 2010. In situ kinetic measurements of gas-solid carbonation of $\mathrm{Ca}(\mathrm{OH})_{2}$ by using an infrared microscope coupled to a reaction cell. Chem. Eng. J. 161, 250-256. doi:10.1016/j.cej.2010.04.041

Neagle, W., Rochester, C.H., 1990. Infrared Study of the Adsorption of Water and Ammonia on Calcium Carbonate. J. Chem. Soc. Faraday Trans. 86, 181-183. doi:10.1039/FT9908600181

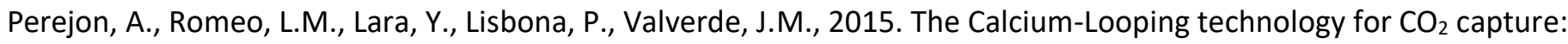
On the important roles of energy integration and sorbent behavior. Appl. Energy 162, 787-807. doi:10.1016/j.apenergy.2015.10.121

Philipp, R., Fujimoto, K., 1992. FTIR Spectroscopic Study of $\mathrm{CO}_{2}$ Adsorption/Desorption on MgO/CaO Catalysts. J. Phys. Chem. 96, 9035-9038. doi:10.1021/j100201a063 
Reddy, E.P., Smirniotis, P.G., 2004. High-Temperature Sorbents for $\mathrm{CO}_{2}$ Made of Alkali Metals Doped on CaO Supports. J. Phys. Chem. B 23, 7794-7800. doi:10.1021/jp031245b

Ridha, F.N., Manovic, V., Macchi, A., Anthony, E.J., 2015. $\mathrm{CO}_{2}$ capture at ambient temperature in a fixed bed with CaO-based sorbents. Appl. Energy 140, 297-303. doi:10.1016/j.apenergy.2014.11.030

Rougé, S., A. Criado, Y., Soriano, O., Abanades, J.C., 2017. Continuous $\mathrm{CaO} / \mathrm{Ca}(\mathrm{OH})_{2}$ fluidized bed reactor for energy storage: first experimental results and reactor model validation. Ind. Eng. Chem. Res. in press. doi:10.1021/acs.iecr.6b04105

Sanchez-Biezma, A., Paniagua, J., Diaz, L., Lorenzo, M., Alvarez, J., Martinez, D., Arias, B., Diego, M.E., Abanades, J.C., 2013. Testing postcombustion $\mathrm{CO}_{2}$ capture with $\mathrm{CaO}$ in a $1.7 \mathrm{MW}$ t pilot facility. Energy Procedia 37, 1-8. doi:10.1016/j.egypro.2013.05.078

Scala, F., Montagnaro, F., Salatino, P., 2007. Attrition of Limestone by Impact Loading in Fluidized Beds. Energy \& Fuels 2566-2572. doi:10.1021/ef0700580

Schroed, R.A., W, C.E., Lippincott, E.R., 1962. Lattice Frequencies and Rotational Barriers for Inorganic Carbonates and Nitrates From Low Temperat ure Infrared Spectroscopy. J. Res. Natl. Bur. Stand. - A. Phys. Chem. 66A, 407434.

Sedghkerdar, M.H., Mahinpey, N., Sun, Z., Kaliaguine, S., 2014. Novel synthetic sol-gel CaO based pellets using porous mesostructured silica in cyclic $\mathrm{CO}_{2}$ capture process. Fuel 127, 101-108. doi:10.1016/j.fuel.2013.08.007

Shimizu, T., Hirama, T., Hosoda, H., Kitano, K., Inagaki, M., Tejima, K., 1999. A Twin Fluid-Bed Reactor For Removal Of $\mathrm{CO}_{2}$ From Combustion Processes. Trans. Inst. Chem. Eng. 77, 62-68. doi:10.1205/026387699525882

Ströhle, J., Junk, M., Kremer, J., Galloy, A., Epple, B., 2014. Carbonate looping experiments in a 1 MW th pilot plant and model validation. Fuel 127, 13-22. doi:10.1016/j.fuel.2013.12.043

Wei, S., Mahuli, S.K., Agnihotri, R., Fan, L., 1997. High Surface Area Calcium Carbonate: Pore Structural Properties and Sulfation Characteristics. Ind. Eng. Chem. Res. 36, 2141-2148. doi:10.1021/ie960768I

Yu, F., Phalak, N., Sun, Z., Fan, L., 2012. Activation Strategies for Calcium-Based Sorbents for $\mathrm{CO}_{2}$ Capture: A Perspective. Ind. Eng. Chem. Res. 51, 2133-2142. doi:10.1021/ie200802y

Zhang, S., Li, X., 2004. Synthesis and characterization of $\mathrm{CaCO}_{3} @ \mathrm{SiO}_{2}$ core-shell nanoparticles. Powder Technol. 141, 75-79. doi:10.1016/j.powtec.2004.02.018

Zhao, M., Shi, J., Zhong, X., Tian, S., Blamey, J., Jiang, J., Fennell, P.S., 2014. A novel calcium looping absorbent incorporated with polymorphic spacers for hydrogen production and $\mathrm{CO}_{2}$ capture. Energy Environ. Sci. 7, 32913295. doi:10.1039/C4EE01281J 